\title{
Review of Broad-Scale Drought Monitoring of Forests: Toward an Integrated Data Mining Approach*
}

Running head: Monitoring drought effects on forests

Steven P. Norman ${ }^{1 \wedge}$, Frank H. Koch ${ }^{2}$, William W. Hargrove ${ }^{1}$

* All authors made equal contributions

${ }^{1}$ USDA Forest Service Southern Research Station, Eastern Forest Environmental Threat Assessment Center, 200 WT Weaver Blvd, Asheville, NC 28804

${ }^{2}$ USDA Forest Service Southern Research Station, Eastern Forest Environmental Threat Assessment Center, 3041 E. Cornwallis Rd., Research Triangle Park, NC 27709

^Corresponding author: tel: 828-259-0535; email: stevenorman@fs.fed.us

Keywords: drought impacts, forests, drought indices, remote sensing, big data, monitoring

Type of paper: Review article for a special drought issue 


\begin{abstract}
Efforts to monitor the broad-scale impacts of drought on forests often come up short. Drought is a direct stressor of forests as well as a driver of secondary disturbance agents, making a full accounting of drought impacts challenging. General impacts can be inferred from moisture deficits quantified using precipitation and temperature measurements. However, derived meteorological indices may not meaningfully capture drought impacts because drought responses can differ substantially among species, sites and regions. Meteorology-based approaches also require the characterization of current moisture conditions relative to some specified time and place, but defining baseline conditions over large, ecologically diverse regions can be as difficult as quantifying the moisture deficit itself. In contrast, remote sensing approaches attempt to observe immediate, secondary, and longer-term changes in vegetation response, yet they too are no panacea. Remote sensing methods integrate responses across entire mixed-vegetation pixels and rarely distinguish the effects of drought on a single species, nor can they disentangle drought effects from those caused by various other disturbance agents. Establishment of suitable baselines from remote sensing may be even more challenging than with meteorological data. Here we review broad-scale drought monitoring methods, and suggest that an integrated datamining approach may hold the most promise for enhancing our ability to resolve drought impacts on forests. A big-data approach that integrates meteorological and remotely sensed data streams, together with other datasets such as vegetation type, wildfire occurrence and pest activity, can clarify direct drought effects while filtering indirect drought effects and consequences. This strategy leverages the strengths of meteorology-based and remote sensing approaches with the aid of ancillary data, such that they complement each other and lead toward a better understanding of drought impacts.
\end{abstract}




\section{Introduction}

Drought is a well-known driver of ecosystem change, yet its occurrence, effects and long-term implications are difficult to recognize and track over large areas (Panu and Sharma, 2002; Hogg et al., 2008). In forests, the reduced moisture levels and high temperatures associated with drought contribute directly to tree stress and mortality (Wang et al., 2012; Anderegg et al., 2013; Millar and Stephenson, 2015). Drought also impacts forests indirectly, by altering the frequency and severity of disturbances such as insect outbreaks or wildfire (Schowalter et al., 1986; Mattson and Haack, 1987; Meyn et al., 2007; Raffa et al., 2008; Trouet et al., 2010; MartínezVilalta et al., 2012). Whether these impacts are direct or secondary, insights from monitoring are typically limited in space and time and inferential in nature. Local observations may be subject to fine-scale nuances that make them unrepresentative of the larger scale. In contrast, broad-scale monitoring of impacts is usually restricted in detail unless change persists long enough to be recognized or until specific changes can be confirmed on the ground with broad-scale surveys.

Fundamentally, our ability to characterize broad-scale drought impacts flows from two types of data: meteorology-based measures and remote-sensing-based measures. Each of these data streams is constrained in its applicability for forests. A multitude of meteorology-based indicators have been developed to estimate moisture deficits in agricultural landscapes, but they may not adequately depict the effects of those deficits across species or vegetation types that exhibit diverse drought responses (Mishra and Singh, 2010; Vicente-Serrano et al., 2012; Peters et al., 2015). As forests and their constituent tree species can have widely disparate levels of drought tolerance, no one indicator is likely to capture the full range of anticipated impacts (Svoboda et al., 2004; Mishra and Singh, 2010; Martínez-Vilalta et al., 2012). For effective 
national- or regional-scale analysis, multiple indicators may be required (Steinemann, 2003; Anderson et al., 2011; AghaKouchak et al., 2015; Park et al., 2016).

Alternatively, remote-sensing-based measures track short-term drought responses by exploiting known differences in reflected radiation between stressed and unstressed vegetation (Peters et al., 1991; Peters et al., 2002; Zhang et al., 2013; Mildrexler et al., 2016). However, short-term stress may not be a sufficient indicator of drought impacts that sometimes take years to emerge (Pasho et al., 2011; Mendivelso et al., 2014; Park et al., 2016). Such slow or delayed responses can reduce our confidence in attributing observed changes to drought, as vegetation changes can result from a number of stressors, including some (e.g., insects and diseases, wildfire) that are influenced by, and therefore confounded with, drought (Westerling et al., 2006; Bigler et al., 2007; Buma and Wessman, 2011; Anderegg et al., 2015). Regardless, attribution of changes observed by remote sensing is challenging without the aid of ancillary data or modeling (Cohen et al., 2016). Even when attribution is possible, the ecological implications of direct and indirect drought effects can be convoluted, since these disturbances may constitute an important and cyclical natural dynamic at timescales that may not be recognized using remote sensing technologies (Peterson et al., 1998; Gunderson, 2000).

Drought impacts are also difficult to resolve in successionally, compositionally or structurally complex landscapes because deciduous and evergreen trees, shrubs, and grasses that comprise these landscapes are not equally sensitive or responsive to drought (Hanson and Weltzin, 2000; Lobo and Maisongrande, 2006; Sims et al., 2014). This is especially true of recently disturbed areas, where the vegetation is in various stages of recovery, as dominant seral species may respond differently to drought through time (Sousa, 1984). Varied responses also occur in highly fragmented landscapes where forest, agriculture, and development are intermixed (Laurance, 
2004; Ewers and Didham, 2006). In such places, it can be problematic to define appropriate baseline conditions for comparison to current observations.

With more than a century of recorded measurements, meteorological station data can provide a robust understanding of baseline conditions at sites, and conditions can be modeled between stations using known topography and meteorological relationships. From this context, it is possible to infer the adaptations of species to climatic regimes and their potential responses to moisture and temperature extremes. However, the relevance of historical climate can be difficult to ascertain in places where forest structure or composition have changed. Additionally, because climate conditions vary across time scales, the appropriate timespan for meaningful climatic baselines is debatable (Lamb and Changnon, 1981; Livezey et al., 2007; Wilks, 2013). Droughtassociated tree mortality can sometimes cause rapid changes in forests (Mueller et al., 2005; Wang et al., 2012), but a long-term successional perspective may be necessary to discern the relative importance of observed changes over the lifespans of trees. Having a relevant temporal context is particularly critical because applicable remotely sensed data have only been available for a few decades, or roughly a third of the time that ground-station-based meteorological data have been available on a wide scale (Choi et al., 2013). While this shorter observation window from remote sensing may limit what we can glean from historical patterns of drought and drought response (AghaKouchak et al., 2015), products derived from satellite data could help to characterize similarities and differences among droughts during recent years, which might be the most relevant time period for some locations of interest.

Near-real-time drought impact monitoring has previously been implemented for agricultural and rangeland systems (Tadesse et al., 2005; Brown et al., 2008), but monitoring impacts is more complicated for forests. Neither meteorological indices nor short-term observations from remote 
sensing, even if used in combination, are likely to be sufficient. For forests, knowledge of both direct and indirect drought impacts, as well as their interactions, is critical (Anderegg et al., 2015; Trumbore et al., 2015), as are insights into the differing drought sensitivities of forest species and communities. Fortunately, a number of ancillary datasets are available that can enhance interpretations and improve predictions, despite the complex drivers involved. For example, landcover or vegetation maps can inform expectations of drought sensitivity. Similarly, datasets that track recent disturbances can isolate various potential causes of change. Fineresolution datasets, such as data collected by systematic field surveys, may be required to understand specific drought impacts. When integrated, these data streams can reduce the uncertainties associated with drought impacts in forested ecosystems.

In this paper, we review important strengths and weaknesses of commonly used meteorologyand remote-sensing-based measures of drought effects. We also describe several existing data sources that could yield useful ancillary information about forest responses to drought. We close by suggesting how integration of these disparate data sources may be a fertile direction for future research. While not intended to be a proof-of-concept, this synthetic direction may be a prescription for more efficient identification of drought effects in forests.

\section{Existing approaches to characterizing drought}

\section{Meteorology-based measures of drought}

Various combinations of precipitation and temperature measurements, usually recorded at weather stations, have been formulated into drought indices that estimate the degree of moisture deficit (or surplus) in some context. (For descriptions of many commonly used indices, see 
Heim, 2002; Keyantash and Dracup, 2002.) Each index is typically associated with a particular class of drought: meteorological, agricultural, or hydrological. For instance, the Palmer Hydrologic Drought Index (PHDI) rebounds less quickly from moisture surpluses or deficits than the similar and more widely used Palmer Drought Severity Index (PDSI), which is generally considered a meteorological drought index (Palmer, 1965). Likewise, the related Palmer Z-index, a measure of agricultural drought, is more sensitive to short-term moisture anomalies than either the PHDI or PDSI.

Meteorology-based drought indices are ordinarily computed on a monthly or weekly time step (e.g., the Crop Moisture Index, or CMI; see Palmer, 1968; Keyantash and Dracup, 2002). Many indices are calculated using a water balance approach between precipitation and potential evapotranspiration (PET), where PET is either calculated using a simple model based largely on temperature (Thornthwaite, 1948), or using a more sophisticated model in which PET may be influenced by changes in humidity, radiation, and wind speed (Monteith, 1965). Several prominent indices represent modifications of the PDSI in response to its perceived limitations (Alley, 1984; Karl, 1986; Guttman, 1998; Keyantash and Dracup, 2002). For instance, the Palmer Modified Drought Index (PMDI) is less volatile than the PDSI, and can more accurately capture a linear combination of temperature and precipitation effects across broad geographic regions (Heddinghaus and Sabol, 1991). The Standardized Precipitation Index (SPI) uses only precipitation data to characterize moisture conditions during multiple, well-defined time windows (McKee et al., 1993); unfortunately, this could be a limitation in the face of increasing recognition that high temperatures magnify drought impacts on trees, and that these impacts are likely to worsen due to climate change (Breshears et al., 2005; McDowell et al., 2008; Allen et al., 2010; Williams et al., 2013; Mitchell et al., 2014; Allen et al., 2015; Mildrexler et al., 2016). 
The Standardized Precipitation Evapotranspiration Index (SPEI) is calculated for multiple time windows like the SPI, but also incorporates PET estimates (Vicente-Serrano et al., 2010). Common to all of these indices is the characterization of "normal" moisture conditions that can be compared with current conditions to determine if they depart from expectations. Generally, normal values are estimated using a long reference period (30 years or more) that is intended to sample natural variation sufficiently (Trenberth et al., 2014).

Unlike annual field crops, most trees within forest communities are tolerant of one or more years of moderate drought stress, so multi-year drought indices are probably most appropriate for forests (Panu and Sharma, 2002; Wilhite et al., 2007; Allen et al., 2010; Mishra and Singh, 2010; Niinemets, 2010). Nevertheless, few researchers have devised and regularly employed drought indices that include multi-year prior conditions of the sort needed when gauging forest impacts. Drought indices consisting of 1-, 3-, and 5-year histories have been utilized in annual national reports issued by the USDA Forest Service Forest Health Monitoring Program (Koch et al., 2013a, b, 2014; Koch and Coulston, 2015; Koch et al., 2015), but these are rare operational examples.

Meteorology-based drought indices benefit from the fact that station-based data are widely available for most portions of the US (and elsewhere), and regional data extend back in time a century or more to provide a relatively consistent climatic context within which to characterize the variability experienced by trees in most forests. A fairly comprehensive meteorological station network was in place for the continental US and Hawaii by the late 1800s (Menne et al., 2012). By comparison, satellites are expensive to launch and cross-calibrate in order to maintain a comparable continuous record (Mendelsohn et al., 2007; Lawrimore et al., 2011; Menne et al., 2012; AghaKouchak et al., 2015). However, the low spatial density of meteorological stations 
necessitates the use of spatial interpolation to create continuous gridded data to determine where drought is occurring and to compare with remotely sensed images. Despite significant methodological advances (e.g., Daly et al., 2002; Daly et al., 2008), spatial interpolation of meteorological data (particularly for phenomena that are highly variable through space, such as rainfall) is still subject to error in heterogeneous terrain and microclimates.

Meteorology-based approaches to characterizing drought have one especially important limitation: they must infer impacts rather than measure them directly. Drought indices only detect moisture deficit in a meteorological sense, and do not predict levels of drought damage or mortality in forests or any other vegetation type. This indirectness is universal, regardless of the drought index selected or of the spatial and temporal coverage provided by the stations used to calculate the index.

\section{Remote-sensing-based measures of drought}

Remote sensing can efficiently track stress responses of forests and other vegetation over large regions at high frequency (Deshayes et al., 2006), yet observed changes still need to be translated to actual impacts on the ground, such as increased tree mortality, annual growth reductions, or secondary (and potentially delayed) drought effects that include changes in wildfire occurrence or behavior as well as insect and disease impacts (Coops et al., 2009; Guindon et al., 2014). Like station data, the high temporal resolution of some remote sensing observations enables real-time or near-real-time monitoring (Zhang et al., 2013). The continuous gridded nature of remote sensing observations can provide an intrinsic advantage over interpolation-dependent meteorological indices, but the spatial advantages of remote sensing are counterbalanced by relatively brief observational histories (Choi et al., 2013; AghaKouchak et al., 2015). 
For remote-sensing-based analyses, it is necessary to match the characteristics of the remotely sensed data stream to the desired spatial and temporal scales. The two Moderate Resolution Imaging Spectrometer (MODIS) sensors have relatively coarse spatial resolution (250-1000 m depending on spectral band), but their fine temporal resolution (1- to 2-day revisit times), seamlessness, consistency, and ease of use make them well-suited to regional- and continentalscale applications (Mildrexler et al., 2007; Coops et al., 2009; Mildrexler et al., 2009). By comparison, the sensors aboard the two currently operational Landsat satellites (Landsats 7 and 8) have inherently finer spatial resolution (30 $\mathrm{m}$ for most spectral bands) and are part of a data record that dates to the early 1970s, but in combination can provide no better than 8-day revisitation for any given location. With this low passover frequency, areas with persistent cloud cover may only be afforded a few clear images per season, and this can confound interpretations of drought duration and severity in areas of rapid phenological change. Furthermore, direct comparison of multi-temporal or adjacent Landsat scenes is complicated by differences in Sunsensor geometry as well as topographic and atmospheric effects, all of which may require complex corrections (Song and Woodcock, 2003). For large-scale analyses utilizing Landsat imagery, such corrections can be laborious and computationally intensive. For example, Hansen et al. (2013) employed advanced cloud computing to correct 20 terapixels from more than 650,000 Landsat images in order to map global forest losses and gains between 2000 and 2012. Similar pro-and-con counterpoints exist for other sensors; in short, higher spatial resolution products are more challenging to scale up to regional and larger areas, but if corrected successfully, can reveal spatial details not captured by coarser resolution products.

Regardless of resolution or revisit frequency, satellite-based sensors integrate vegetation conditions across the entire grid cell at the spatial resolution of the sensor, averaging across 
vegetation types and plant species (Deshayes et al., 2006). The trajectory of such integrating measures across seasons has been referred to as land surface phenology (LSP, de Beurs and Henebry, 2004). Inter-annual differences in the timing and magnitude of LSP have been suggested as potential indicators of environmental change, including drought.

A variety of remote sensing indices (see Zhang et al., 2013 for a review) have been developed, but these measures only capture certain impacts of drought and other disturbance to vegetation, including forests. Initially conceived by Rouse et al. (1973) and popularized by Tucker (1979), the Normalized Difference Vegetation Index (NDVI) has proven to be a fertile starting point, and many variants of this index have been devised. NDVI exploits the differential responses of stressed and healthy vegetation across the red and near-infrared wavelengths. Chief among its advantages is the normalization for differences in sun-and-sensor geometry that is provided by the "difference-over-sum" format of its arithmetic construction. Although the relationship between NDVI and Leaf Area Index may be non-linear in dense vegetation like tropical rainforests (Huete et al., 2002), many remote sensing indices (e.g., the Vegetation Condition Index, or VCI; see Kogan, 1995) work by tracking changes in NDVI, under the assumption that changes in photosynthesis can be used to infer drought impacts. This approach is also used by the USDA Forest Service's ForWarn system, which tracks various forest disturbances, including drought (Hargrove et al., 2009; Figure 1). Notably, changes in satellite NDVI may better indicate plant health status and vigor in deciduous trees than in the evergreen foliage of conifers, which may experience a decline in photosynthesis and related plant functions without a corresponding reduction in NDVI (Gamon et al., 1995).

Most remote sensing indices compare change in the current state with a calendrically comparable period of a previous year or set of years (Peters et al., 2002). This fixed-date comparative 
approach makes isolating drought responses during seasonal green-up or brown-down particularly difficult, as year-to-year phenological timing often varies by a week or two (Schwartz and Hanes, 2010). Such variation can obscure recognition and measurement of the seasonal effects of drought and any other disturbance. Comparison of the current value with an historical calendric "normal" is borrowed from meteorology where expectations are not nuanced by phenology. However, as with the meteorological approach, the defined "normal" may be the local value at the same time the previous year, it may be the mean, median or maximum value from a number of prior years, or it may be scaled to the full dynamic range of the local value (Hargrove et al., 2009). Differences in the mechanism used to characterize this normal baseline are responsible for much of the proliferation of alternative forms of basic indices like NDVI (Zhang et al., 2013). Indeed, it may be more challenging to determine the normal, expected trend than it is to monitor the current status, whether by meteorology-based or remotely sensed impact metrics. Because short-term vegetation responses may not necessarily reflect long-term impacts (Pasho et al., 2011; Mendivelso et al., 2014), the multiple-year monitoring capabilities that remote sensing provides are critical for separating short-term drought responses from those that are delayed or long-lasting.

Remote sensing data, even high temporal or spatial resolution data, are insufficient alone to unequivocally demonstrate that drought is the causal agent of a particular change in reflectance values. Interpretation of remotely sensed products may not be straightforward, and interpretations can be complicated by both the technical aspects of the sensor technologies, as well as by the intricacies and interconnections of underlying ecological processes (AghaKouchak et al., 2015). Difficulties in interpreting remotely sensed data have been demonstrated by a recent controversy regarding the apparent green-up of Amazon forests during a severe drought in 2005 
(Myneni et al., 2007; Saleska et al., 2007; Samanta et al., 2011; Morton et al., 2014). Wu et al. (2016), by combining elaborate ground and tower measurements with remotely sensed data across a rainfall gradient, found that coordinated leaf development and demography may explain large increases in ecosystem photosynthesis during dry conditions. An all-data approach such as this, where remote sensing methods are leveraged with other supplementary data streams, including ground-based measurements, may represent the most promising approach for cohesively and coherently addressing drought effects at broad scales (AghaKouchak et al., 2015; Cohen et al., 2016; Moore et al., 2016). A number of integrated wide-area monitoring systems have been developed that loosely follow this type of conceptual model, including the US Drought Monitor (Svoboda et al., 2002) and the related North American Drought Monitor (Lawrimore et al., 2002). Nevertheless, no current integrated wide-area drought monitoring system specifically focuses on drought stress in forested ecosystems.

Remote sensing provides a coarse-filter type approach. Observations are frequent, extensive, and continuous in space, but are not detailed, and average across many vegetation types. Sensors are not species-specific; instead, they integrate across all vegetation growing in an area (i.e., an image pixel) to produce a single value (Deshayes et al., 2006). Such integration may actually reduce noise, measuring the LSP signal as a repeatable, emergent property of the entire vegetated ecosystem.

\section{Filtered monitoring with ancillary datasets}

Remote sensors observe stress responses from all disturbances, not only from drought. These responses can be difficult to disentangle without ancillary insights. Because drought sensitivity 
and biotic impacts are seasonal (Hanson and Weltzin, 2000; Volaire and Norton, 2006), datasets that convey changes in phenological behavior are particularly useful. Large-scale disturbance datasets, including insect and disease surveys and wildfire locations, suggest where current conditions or baselines may influence our interpretation of drought effects. Vegetation type and land cover datasets can help isolate those places that are most and least likely to provide clear indicators of drought. Integrating such ancillary datasets with meteorology-based indices and remote sensing observations can refine interpretations, and may be required to document drought impacts in forests at broad scales. In the following sections and in Table 1, we highlight some example datasets, applicable to US forests, that can help filter the drought signal from remote sensing and meteorological data (Figure 2).

\section{Land surface phenology datasets}

Departures of LSP from seasonal expectations can provide one of the earliest indications of direct drought effects, but not in isolation. Declines in growing season productivity can indicate drought stress, particularly when they occur on drought-sensitive sites. In deciduous forests, drought may trigger early leaf senescence and the early onset of fall (Hwang et al., 2014), and drought and frost hazard may be related (Vitasse et al., 2009). While observed changes in LSP may be related to other climate and disturbance factors, LSP can be highly responsive to drought stress, particularly in locations that harbor drought-sensitive species and at drought-sensitive times of the year. NDVI is available, for example, from the two MODIS sensors globally as a standard NASA product (MOD 13) at spatial resolutions as fine as $250 \mathrm{~m}$ and temporal resolutions as fine as 16 days, phased 8 days apart. Examples of LSP datasets are listed in Table 1. 
The seasonal phenological behavior of species drive how they respond to drought over the year, and this determines how sensitive remote sensing efforts may be for detecting stress at a particular time. Conifers remain green even while dormant, potentially delaying LSP effects from drought impacts until long after the original drought events occurred. Deciduous woody plants and grasses can have extended periods of brown dormancy that can detect, mimic, or hide drought conditions (Volaire and Norton, 2006). The LSP of drought-sensitive grasses in opencanopy forests, savannas, or forest edges may exhibit more responsiveness to drought than closed forests. This disparate responsiveness of land surface phenology can be isolated using ancillary data, but it can be challenging to distinguish when the remote sensing signal is responding to drought stress only, or to some other combination of disturbances. While vegetation response to drought is muted outside the growing season, winter drought can cause needle loss and reduction in net primary productivity in conifers that can be detected remotely under controlled conditions (Berg and Chapin, 1994).

Remotely sensed observations of snowpack provide a useful indicator of winter drought in portions of the West. At high elevations, reduced snowpack can lead to an early onset of spring green-up (Hu et al., 2010), although this phenological shift may also result from faster snowmelt from warmer late winter and spring temperature. Earlier green-up from a drought-associated reduction in snowpack will not be observed as stress, but as an increase in greenness, relative to expectations. Winter drought can also influence the subsequent wildfire season (Westerling et al., 2006; Littell et al., 2009) and early green-up may affect drought-associated insects and diseases (Ayres and Lombardero, 2000). While seasonal changes in LSP provide a sensitive but complex and confounded measure of stress and climate, mapping departures in LSP can improve 
our understanding of where drought is occurring relative to sparse meteorological stations (Table 1).

Insect and disease surveys

The insect and disease aerial survey program (IDS; see Table 1), administered by USDA Forest Service Forest Health Protection, serves as a national-scale source of geospatial data about biotic impacts triggered by drought. In some cases, IDS data also document direct impacts from drought and other abiotic disturbance agents. Under the program, geospatial features (typically polygons) depicting forest health impacts (tree mortality, defoliation, or discoloration) are delineated by surveyors, flying in light aircraft, via aerial sketch-mapping hardware and software. The surveyors assign disturbance agent codes and certain measures of the intensity of the impact (e.g., trees per acre defoliated), to each feature. IDS data are compiled on an annual basis, and so are not sources of near-real-time information.

Meddens et al. (2012) noted several additional obstacles to using the IDS data. First, the amount of forest surveyed varies from year to year, and not all forests are surveyed; flights are targeted at areas where disturbances are most likely to have occurred (according to ground reports), so some affected areas may be missed. Second, IDS polygons are delineated broadly, and they typically also include healthy trees. Hence, the severity of a disturbance is not reported consistently. IDS polygons are drawn by different observers having a wide range of skills and experience, introducing further variability. Efforts are currently underway to change how severity is reported (i.e., as extent of area affected instead of the density of trees affected), which should improve data consistency. 
Depending on the aerial surveyor, IDS polygons could, for instance, be labeled as having been caused by drought, or instead by insect activity driven by drought; causal attribution is done from the aircraft, without field validation. To circumvent such ambiguities when analyzing piñon and juniper mortality in the southwestern United States, Breshears et al. (2005) combined IDS polygons attributed to various bark beetles as well as drought. This example suggests that IDS data are probably best used to delineate localities where multiple years of forest damage and/or mortality have been linked to a complex of biotic and abiotic agents that are generally associated with drought (Huang and Anderegg, 2012). These localities could then be adopted as an appropriate setting for further retrospective analysis into relationships between the agents, using other data sources (e.g., Williams et al., 2010; Williams et al., 2013).

\section{Wildland fire datasets}

Although wildland fire impacts are often an indirect consequence of drought (Westerling et al., 2006), areas that have been burned are less likely to yield a consistent measure of direct drought effects than are adjacent undisturbed areas. Increases in grass or shrub cover after fire may make burned landscapes more climate-sensitive than when they were dominated by dense conifers (Vicente-Serrano et al., 2013; Sims et al., 2014), and early post-fire succession typically involves rapid changes in species that may also have different drought sensitivities. Nevertheless, existing wildfire datasets (see Table 1) can be used to isolate burned portions of the landscape, thus providing a more accurate understanding of the behavior of burned and unburned areas. As with insect and disease data, burned areas can be selectively masked out so they do not unduly influence regional-scale interpretations of drought responses, or they could be specifically targeted for evaluating the cumulative effects of drought and other disturbances. 
The 2011 Texas drought and drought-associated fires illustrate how remote-sensing-based change monitoring can be better interpreted using supplementary wildland fire data. This drought was remarkable because of its severity and duration, and because of the extensive area burned during the 2011 wildfire season (Nielsen-Gammon, 2012). An estimated $6.2 \%$ of all live trees died statewide (Moore et al., 2016). Where and when they co-occur, drought and wildfire may have additive or redundant effects in reducing NDVI. For two nearby MODIS pixels in Figure 3, the effects of fire and drought are at least partially additive. The NDVI of these two pixels tracks each other closely for years prior to 2011, suggesting they had quite similar vegetation, and the 2011 drought effects were likely identical given their proximity. However, the immediate reduction from burning and drought clearly exceeded that of drought alone, and this effect persisted through 2012.

\section{Land use/land cover datasets}

With slow rates of change, shifts in land use or land cover are unlikely to influence large-scale drought detection by remote sensing, but, over decades, many landscapes have experienced substantial urban and infrastructural development (Riitters et al., 2002; Riitters and Wickham, 2003). Logging, stand thinning or conversion from forest to non-forest use often increases dominance by grass, shrubs, or other early-successional species that are generally more responsive to drought than are closed forests (Vicente-Serrano et al., 2013; Sims et al., 2014). In areas that have experienced these changes, baselines from long-term, remotely sensed time series may be less useful for understanding drought response, particularly when land use/land cover change has occurred gradually over a period of years. For the United States, the Landsat-based National Land Cover Database (NLCD; see Table 1) provides complete national coverage for multiple time steps (1992, 2001, 2006, and 2011), allowing analysts to distinguish patterns of 
land cover change that may be pertinent for isolating areas that are less likely to have a reliable drought response.

More subtle changes in forest management, crop type, or livestock grazing intensity can be difficult to track and assess. Similarly, broad-scale forest restoration that involves stand thinning, via mechanical means or prescribed fire, has the potential to reduce a forest's sensitivity to drought by changing grass and shrub cover; yet restoration efforts are rarely extensive enough to be widely detected via moderate-resolution satellite imagery. Far less logging has occurred over the last decade on most Forest Service lands than previously (USDA Forest Service, 2015), suggesting that there was more drought-sensitive early successional habitat during the 1980s than exists in the 2000s. Conversely, as large wildfires become increasingly common in the West, extensive areas of what was once closed-canopy forest will likely become more droughtsensitive than before. Certain derived land use/land cover datasets, such as the percent tree canopy cover layer developed by the Forest Service for the 2011 NLCD (Coulston et al., 2012), may offer some insights into these landscape changes.

The usefulness of filtering drought responses by land cover type is illustrated by different sensitivities of a random sample of MODIS pixels across west Texas. Annual fluctuation in NDVI clearly varies by majority vegetation type, as filtered by the National Land Cover Dataset (Figure 4). Grass-dominated areas have greater year-to-year amplitude in NDVI, consistent with their climate-sensitive variation in productivity. After 2010, all vegetation types decline, indicating either mortality or continued low productivity from persistent drought effects. 


\section{"Big data" integration for understanding drought effects}

Meteorology- and remote-sensing-based approaches excel at identifying and contextualizing drought occurrence, yet quantifying specific drought impacts typically require further assessment and data from the field. Insights from remote sensing can be improved by consideration of ancillary datasets that filter or help contextualize observed changes (Table 1; Figure 2). Filtering by vegetation type and disturbance history may be particularly useful for determining where drought has occurred or is ongoing, and to isolate more specific drought responses. For example, areas of potential drought impacts are better revealed after filtering out areas with recent wildfire, insect and disease impacts, or by focusing on individual vegetation types, and then relating NDVI responses to the Palmer Modified Drought Index (PMDI) (Figure 5).

The 240 m (i.e., MODIS) resolution maps in Figure 5 show correlations between NDVI and PMDI for a 13-year period, 2000-2012. During this period, the response of NDVI to drought differed among vegetation types, but also regionally. Across most of the West and Southeast, the NDVI of conifer (Figure 5B) and hardwood (Figure 5C) forests decreased with worsening drought, as shown by positive correlations (yellow to red). Yet, forested portions of the Pacific Northwest and Northeast had higher NDVI values during drier years, resulting in negative correlations (green to blue). The strongest and most consistently positive correlations were associated with shrub (Figure 5D) and grasslands (Figure 5E), suggesting that these cover types are particularly sensitive to declines in NDVI as drought increases in severity. Thus, forests in areas with highly fragmented land cover, such as the Southeast, or open forest types with grass ground cover, as are common in the Interior West, may exhibit drought sensitivity that relates to the mixed composition (i.e., high grass proportion) of their constituent pixels. Conversely, the 
denser forests of the Northeast and Pacific Northwest may be less responsive to drought because grass is comparatively less extensive (Figure 5B, C).

Correlative patterns are probably further nuanced by regional differences in drought severity during the MODIS era. While most of the West and Southeast experienced extreme variation in growing season PMDI between 2000 and 2012, the same cannot be said for the Northeast. In the Northeast, a decrease in NDVI despite increased wetness for forests and crops may have resulted from less sun or cooler temperatures during the wetter years, with extreme drought, and its expected detrimental effects, absent from the analytical period.

Importantly, correlations are likely to be unreliable in areas that have experienced severe disturbance. In Figure 5A and 5B, Western conifer forests that were disturbed (as shown in black in Figure 5A) often showed a weaker correlation between NDVI and PMDI than adjacent undisturbed forests. In contrast, Northeastern hardwood forest disturbances, which are usually of smaller extent and shorter duration, had less impact on growing season NDVI and its correlation with PMDI, with disturbed forests remaining fairly similar to adjacent undisturbed forests (Figure 5A, 5C).

As the area affected by severe disturbance increases with megafires and insect and disease mortality across the West in particular (Cohen et al., 2016), our ability to consistently distinguish drought stress from disturbance effects will diminish. Using a random sample of 250,000 points, we found that $20.4 \%$ of the continental US forest area was mapped as disturbed by wildfire, insects, or diseases between 2000 and 2012, and this may be a conservative estimate given limitations of mapping (estimated using IDS, MTBS, and GeoMAC data; see Table 1). Disturbance or recovery responses may either dominate the signal or subtly alter the drought 
sensitivity of sites over time. For example, a gradual increase in NDVI associated with postdisturbance succession and recovery may overwhelm reductions in NDVI caused by moderate drought (Figure 3). By masking out disturbed forests, however, the response of the remaining areas is more likely to be caused by direct drought effects (Figure 5A). Analysis can be further filtered to focus on the subset of remaining areas that have experienced measureable drought stress according to one or more meteorological indices.

\section{The role of fine-scale monitoring}

Broad-scale drought monitoring from meteorological indices or remote sensing has limits, and most detailed drought impacts can only be addressed through focused finer-scale observations. For monitoring efficiency, insights from broad monitoring can help prioritize areas for detailed investigation. Such targeted efforts might consist of detailed mapping of specific locations of interest using high-resolution imagery in the United States and other countries with national forest inventories (McRoberts and Tomppo, 2007). Effects can then be confirmed or refined with systematic field-based monitoring of species or vegetation responses. Such field observations only become available several years later than meteorological station or remote sensing data streams. However, field-based monitoring directly tracks indicators such as tree growth and mortality that can provide a reasonably precise picture of forest status.

For example, the US Forest Service Forest Inventory and Analysis (FIA) program administers an annualized system of field plot inventories. Under this system, first implemented in the late 1990s, plots are re-measured systematically on a cycle ranging from five (eastern United States) to ten years (western United States). Thus, in the western United States, one-tenth of the established FIA plot locations in any given state are sampled each year. These annual samples 
attempt to be free of geographic bias (Shaw et al., 2005), appear to be sufficient for annual time series analysis of forest growth and mortality, and are able to detect relatively low levels of some types of forest change (Shaw et al., 2005). However, it may be impractical to link a short-term (e.g., single-year) drought event to mortality or other impacts observed on a plot, since the exact timing of that impact (i.e., exactly when during the several years since the plot was last visited) cannot be determined (Liknes et al., 2012). Multiple-decade trends typically must be studied using a combination of annualized and older periodic inventory data between which there may have been substantive methodological differences.

Because of their sampling density (roughly one plot per 6,000 forested acres), FIA data may be unable to detect impacts that are patchy in nature, even if they are manifested over a relatively large geographic region (Liknes et al., 2012). Unfortunately, drought-induced tree mortality is often patchy (Allen et al., 2010). Despite this limitation, Gustafson and Sturtevant (2013) concluded that a drought-induced tree mortality signal in the upper Great Lakes region could be uncovered using FIA data. Gustafson (2014) similarly used FIA data to construct predictive models of drought-induced tree mortality (based in part on correlation with the PDSI and SPI) in the northeastern US. He found that the reliability of these models varied substantially. In particular, models for drought-intolerant tree species performed most poorly. Gustafson hypothesized that this may have occurred because long drought periods did not occur in the Northeast during the period when FIA inventories were available.

Ultimately, the best use of FIA data may be for retrospective and/or confirmatory analyses linking tree mortality and reduced growth to drought. FIA data might be used in concert with a variety of other data sources, including tree-ring data, remote sensing, meteorological drought index maps, and others. A number of studies have employed this multivariate approach (e.g., 
Shaw et al., 2005; Klos et al., 2009; Dietze and Moorcroft, 2011; Williams et al., 2013), albeit on a limited scale. Through specially commissioned FIA re-measurement surveys, it may be possible to quantify areas experiencing major forest impacts in terms of trees lost and extent of the affected area, as was done by the Texas A\&M Forest Service after the exceptional Texas drought in 2011, with use of MODIS-based ForWarn data products (Nielsen-Gammon, 2012; Moore et al., 2016).

We have heretofore argued that spatially coarse- but temporally fine-resolution satellite data (e.g., from the MODIS sensors) are well suited to serve as the primary remote sensing data stream in a system for monitoring broad-scale drought occurrence and impacts in forests (see Figure 2). The value of these data comes from their efficiency, expediency, and relative seamlessness. By comparison, the difficulties of processing and applying finer-resolution satellite data (e.g., from the Landsat sensors) in a wall-to-wall fashion for large geographic areas render them far less practical for broad-scale and near-real-time monitoring. Nevertheless, finerresolution remotely sensed data, like FIA data, can fill a crucial investigative role with respect to drought and its relationship with forest health and mortality. For instance, McDowell et al. (2015) proposed a global-scale framework for vegetation disturbance monitoring that combines MODIS data with Landsat (and other data sources) that are better for analyzing localized disturbances; the researchers argued that multi-scale analysis is necessary to detect subtle, slowdeveloping changes, such as might be caused by increasing temperatures under a changing climate. Cohen et al. (2016) highlighted another way Landsat data could be employed retrospectively for broad-scale forest disturbance analysis. They employed TimeSync, a software package and approach for collecting disturbance data and analyzing time series of Landsat data, to interpret 7200 pixels selected via a two-stage, stratified random sampling process. Scaling up 
these interpretations to characterize conditions in the conterminous U.S. between 1985 and 2012, they found that forest decline had surpassed forest harvest by the mid-1990s.

Besides Landsat, other fine-resolution data could also serve as fruitful sources of information about drought impacts in forests. Asner et al. (2016) used a combination of airborne laser-guided imaging spectroscopy (i.e., High-Fidelity Imaging Spectroscopy, or HiFIS), satellite and environmental data, and geostatistical modeling to assess changes in the canopy water content of California's forests between 2011 and 2015. Their maps of progressive canopy water stress identify locations of at-risk forests, and they predict substantial future forest changes if current drought conditions persist with climatic change. Like the previous examples, the work described by Asner et al. (2016) illustrates the potential value that some finer-resolution remotely sensed data may have for filtering a more synoptic, yet coarser-resolution, remotely sensed data stream (as well as a meteorological data stream) in our proposed drought monitoring system (Figure 2).

\section{Advancing "big data" science}

Wide spatial coverage and frequent, multi-year temporal sampling are powerful strengths of remote-sensing-based approaches to the analysis of drought effects. It is not possible to do experiments on drought at the landscape scale. The extent is too large to randomize, to replicate, or to apply droughts as experimental treatments (but see the Walker Branch Throughfall Displacement Experiment near Oak Ridge, Tennessee, described by Hanson et al., 2003). Nonetheless, an inability to apply the classical scientific method does not prevent a remote sensing approach to drought effects from making progress (Hargrove and Pickering, 1992). Scientific progress on drought effects at large scales is simply limited to inference, based on what we can see happening. In this, broad-scale monitoring of drought is similar to astronomy, in 
which rich observation without the possibility of direct manipulation may be the only avenue for advancement.

A filtering approach that carefully considers both vegetative and climatic conditions can leverage the strengths of extensive data collected with remote sensing to best advantage. The identification of past situations whose drought outcomes might be informative or discriminating forms the keystone of this approach. A cycle starting with the postulation of an hypothesis, followed by identification and selection of relevant past "natural" experiments, followed by observation of the outcomes that resulted could be expected to produce inferences about the general principles at work. Such inferences would, in turn, result in refinement or rejection of hypotheses, beginning the cycle anew.

Such context-based learning, involving the isolation and examination of relevant prior circumstances, would leverage the availability of "big data" volumes of historical observations. Essentially a form of empirical data mining, this type of time sequence approach is sometimes called space-for-time substitution, a technique that has been successfully employed elsewhere in large-scale ecology (Pickett, 1989). Figure 5 demonstrates the utility of such a filtering approach by showing the differential responses of various vegetation types to drought.

Empowered by ancillary datasets, powerful post hoc opportunistic analyses of drought may be possible when advantage can be taken of past droughts that are embedded within these specific relevant contexts of particular past times and locations. Such observation-based approaches carry with them the dangers of pseudoreplication, or at least an inability to replicate at will (Hurlbert, 1984). Nevertheless, a strategy of coarse filtering by vegetation type, antecedent conditions, and drought severity (e.g., as determined using meteorological indices) could obtain targeted insights 
based on the weight of evidence from past outcomes. Searching an extensive database of observations for the occurrence and review of particularly relevant chronosequences in time and space might be an effective way to make observation-based progress in our understanding of drought effects.

While remote sensing is invaluable for mapping drought responses at finer resolution than is possible from weather station data or gridded meteorological models, remote sensing approaches are sensitive to much more than drought. As suggested in Figure 2, that breadth can be managed by incorporating the meteorological data stream - essentially as a first filter - and then further filtering expectations using phenological and disturbance datasets. Some of those datasets are especially useful for addressing and monitoring indirect drought effects, such as from wildfire, insects or diseases over time.The general strategy is empirical, allowing patterns to emerge passively from the data. Despite their neutrality and passive observational nature, space-for-time filtering approaches can generate large numbers of testable hypotheses for subsequent iterations of conditional testing (Tilman, 1989).

Unambiguous establishment of causation (even in a limited pragmatic sense of learning to recognize correlated antecedent conditions) is difficult using these observational methods. With drought, however, this difficulty in separating proximate from ultimate drivers may not matter. Managers may be satisfied to monitor combined cumulative primary and secondary drought effects, unless they feel that they possess management options that would be effective against one or more of the separated drivers. Otherwise, in practical terms, it is the sum total of the cumulative effects that act to reduce the productivity of their forests. 
Many of the newest generation of remote-sensing-based drought monitoring systems (e.g., the Vegetation Drought Response Index, or VegDRI; see Brown et al., 2008) are adopting such multivariate approaches. These approaches appropriately mirror the multivariate nature of drought effects and impacts themselves. Combined with ground-based sampling and monitoring data, such a hybrid approach can inform and enlighten our understanding of drought effects on forests.

\section{Conclusions}

There is much recent interest in understanding how drought affects forests, in part because drought and drought-associated disturbances are expected to increase with climatic change (e.g., Breshears et al., 2005; Westerling et al., 2006; Adams et al., 2009; Breshears et al., 2009; Allen et al., 2010; Carnicer et al., 2011; Anderegg et al., 2012; Martínez-Vilalta et al., 2012; Allen et al., 2015; Millar and Stephenson, 2015; Clark et al., in press). Existing technologies and monitoring systems allow us to anticipate where drought stress and potential impacts to forests are likely to occur, yet our ability to systematically and accurately recognize precise drought impacts is limited. Ideally, we would address drought impacts to forests at a resolution that is useful for preventative or remedial action. For some purposes, that scale is regional, but for the purposes of restoration or ensuring resilience, the need is often local. As relevant datasets become more prevalent and improve in quality, more aggressive use of big data can help build that contextual understanding. 


\section{Acknowledgements}

We thank the Eastern and Western Threat Assessment Centers and Forest Health Monitoring Program of the USDA Forest Service for continued support in many forms. We also thank the editors of this special issue and anonymous reviewers. This manuscript was condensed and augmented from General Technical Report SRS-207, U.S. Department of Agriculture Forest Service, Southern Research Station, Washington, DC, 199 pgs.

\section{References}

Adams, H.D., Guardiola-Claramonte, M., Barron-Gafford, G.A., Villegas, J.C., Breshears, D.D., Zou, C.B., Troch, P.A., Huxman, T.E., 2009. Temperature sensitivity of drought-induced tree mortality portends increased regional die-off under global-change-type drought. P. Natl. Acad. Sci. USA 106, 7063-7066.

AghaKouchak, A., Farahmand, A., Melton, F.S., Teixeira, J., Anderson, M.C., Wardlow, B.D., Hain, C.R., 2015. Remote sensing of drought: Progress, challenges and opportunities. Rev. Geophys. 53, 452-480.

Allen, C.D., Breshears, D.D., McDowell, N.G., 2015. On underestimation of global vulnerability to tree mortality and forest die-off from hotter drought in the Anthropocene. Ecosphere 6, 1-55. Allen, C.D., Macalady, A.K., Chenchouni, H., Bachelet, D., McDowell, N., Vennetier, M., Kitzberger, T., Rigling, A., Breshears, D.D., Hogg, E.H., Gonzalez, P., Fensham, R., Zhang, Z.,

Castro, J., Demidova, N., Lim, J.H., Allard, G., Running, S.W., Semerci, A., Cobb, N., 2010. A global overview of drought and heat-induced tree mortality reveals emerging climate change risks for forests. For. Ecol. Manage. 259, 660-684. 
Alley, W.M., 1984. The Palmer Drought Severity Index: limitations and assumptions. J. Clim. Appl. Meteorol. 23, 1100-1109.

Anderegg, L.D.L., Anderegg, W.R.L., Berry, J.A., 2013. Not all droughts are created equal: translating meteorological drought into woody plant mortality. Tree Physiol. 33, 672-683.

Anderegg, W.R.L., Berry, J.A., Smith, D.D., Sperry, J.S., Anderegg, L.D.L., Field, C.B., 2012. The roles of hydraulic and carbon stress in a widespread climate-induced forest die-off. P. Natl. Acad. Sci. USA 109, 233-237.

Anderegg, W.R.L., Hicke, J.A., Fisher, R.A., Allen, C.D., Aukema, J., Bentz, B., Hood, S., Lichstein, J.W., Macalady, A.K., McDowell, N., Pan, Y., Raffa, K., Sala, A., Shaw, J.D., Stephenson, N.L., Tague, C., Zeppel, M., 2015. Tree mortality from drought, insects, and their interactions in a changing climate. New Phytol. 208, 674-683.

Anderson, M.C., Hain, C., Wardlow, B., Pimstein, A., Mecikalski, J.R., Kustas, W.P., 2011. Evaluation of drought indices based on thermal remote sensing of evapotranspiration over the continental United States. J. Climate 24, 2025-2044.

Asner, G.P., Brodrick, P.G., Anderson, C.B., Vaughn, N., Knapp, D.E., Martin, R.E., 2016. Progressive forest canopy water loss during the 2012-2015 California drought. P. Natl. Acad. Sci. USA 113, E249-E255.

Ayres, M.P., Lombardero, M.J., 2000. Assessing the consequences of global change for forest disturbance from herbivores and pathogens. Sci. Total Environ. 262, 263-286.

Berg, E.E., Chapin, F.S., 1994. Needle loss as a mechanism of winter drought avoidance in boreal conifers. Can. J. For. Res. 24, 1144-1148.

Bigler, C., Gavin, D.G., Gunning, C., Veblen, T.T., 2007. Drought induces lagged tree mortality in a subalpine forest in the Rocky Mountains. Oikos 116, 1983-1994. 
Breshears, D.D., Cobb, N.S., Rich, P.M., Price, K.P., Allen, C.D., Balice, R.G., Romme, W.H., Kastens, J.H., Floyd, M.L., Belnap, J., Anderson, J.J., Myers, O.B., Meyer, C.W., 2005. Regional vegetation die-off in response to global-change-type drought. P. Natl. Acad. Sci. USA $102,15144-15148$.

Breshears, D.D., Myers, O.B., Meyer, C.W., Barnes, F.J., Zou, C.B., Allen, C.D., McDowell, N.G., Pockman, W.T., 2009. Tree die-off in response to global change-type drought: mortality insights from a decade of plant water potential measurements. Front. Ecol. Environ. 7, 185-189. Brown, J.A., Wardlow, B.D., Tadesse, T., Hayes, M.J., Reed, B.C., 2008. The Vegetation Drought Response Index (VegDRI): a new integrated approach for monitoring drought stress in vegetation. GISci. Remote Sens. 45, 16-46.

Buma, B., Wessman, C.A., 2011. Disturbance interactions can impact resilience mechanisms of forests. Ecosphere 2, art64.

Carnicer, J., Coll, M., Ninyerola, M., Pons, X., Sánchez, G., Peñuelas, J., 2011. Widespread crown condition decline, food web disruption, and amplified tree mortality with increased climate change-type drought. P. Natl. Acad. Sci. USA 108, 1474-1478.

Choi, M., Jacobs, J.M., Anderson, M.C., Bosch, D.D., 2013. Evaluation of drought indices via remotely sensed data with hydrological variables. J. Hydrol. 476, 265-273.

Clark, J.S., Iverson, L., Woodall, C.W., Allen, C.D., Bell, D.M., Bragg, D.C., D'Amato, A.W., Davis, F.W., Hersh, M.H., Ibanez, I., Jackson, S.T., Matthews, S., Pederson, N., Peters, M., Schwartz, M.W., Waring, J.M., Zimmermann, N.E., in press. The impacts of increasing drought on forest dynamics, structure, and biodiversity in the United States. Global Change Biol. doi: 10.1111/gcb.13160. 
Cohen, W.B., Yang, Z., Stehman, S.V., Schroeder, T.A., Bell, D.M., Masek, J.G., Huang, C., Meigs, G.W., 2016. Forest disturbance across the conterminous United States from 1985-2012: The emerging dominance of forest decline. For. Ecol. Manage. 360, 242-252.

Coops, N.C., Wulder, M.A., Iwanicka, D., 2009. Large area monitoring with a MODIS-based Disturbance Index (DI) sensitive to annual and seasonal variations. Remote Sens. Environ. 113, $1250-1261$.

Coulston, J.W., Moisen, G.G., Wilson, B.T., Finco, M.V., Cohen, W.B., Brewer, C.K., 2012. Modeling percent tree canopy cover: a pilot study. Photogramm. Eng. Rem. S. 78, 715-727. Daly, C., Gibson, W.P., Taylor, G.H., Johnson, G.L., Pasteris, P., 2002. A knowledge-based approach to the statistical mapping of climate. Clim. Res. 22, 99-113.

Daly, C., Halbleib, M., Smith, J.I., Gibson, W.P., Doggett, M.K., Taylor, G.H., Curtis, J., Pasteris, P.P., 2008. Physiographically sensitive mapping of climatological temperature and precipitation across the conterminous United States. Int. J. Climatol. 28, 2031-2064. de Beurs, K.M., Henebry, G.M., 2004. Land surface phenology, climatic variation, and institutional change: Analyzing agricultural land cover change in Kazakhstan. Remote Sens. Environ. 89, 497-509.

Deshayes, M., Guyon, D., Jeanjean, H., Stach, N., Jolly, A., Hagolle, O., 2006. The contribution of remote sensing to the assessment of drought effects in forest ecosystems. Ann. For. Sci. 63, 579-595.

Dietze, M.C., Moorcroft, P.R., 2011. Tree mortality in the eastern and central United States: patterns and drivers. Global Change Biol. 17, 3312-3326.

Ewers, R.M., Didham, R.K., 2006. Confounding factors in the detection of species responses to habitat fragmentation. Biol. Rev. 81, 117-142. 
Gamon, J.A., Field, C.B., Goulden, M.L., Griffin, K.L., Hartley, A.E., Joel, G., Penuelas, J., Valentini, R., 1995. Relationships between NDVI, canopy structure, and photosynthesis in three Californian vegetation types. Ecol. Appl. 5, 28-41.

Guindon, L., Bernier, P.Y., Beaudoin, A., Pouliot, D., Villemaire, P., Hall, R.J., Latifovic, R., StAmant, R., 2014. Annual mapping of large forest disturbances across Canada's forests using 250 m MODIS imagery from 2000 to 2011. Can. J. For. Res. 44, 1545-1554.

Gunderson, L.H., 2000. Ecological resilience--in theory and application. Annu. Rev. Ecol. Syst. $31,425-439$.

Gustafson, E.J., 2014. Applicability of predictive models of drought-induced tree mortality between the midwest and northeast United States. Forest Sci. 60, 327-334.

Gustafson, E.J., Sturtevant, B.R., 2013. Modeling forest mortality caused by drought stress: implications for climate change. Ecosystems 16, 60-74.

Guttman, N.B., 1998. Comparing the Palmer Drought Index and the Standardized Precipitation Index. J. Am. Water Resour. As. 34, 113-121.

Hansen, M.C., Potapov, P.V., Moore, R., Hancher, M., Turubanova, S.A., Tyukavina, A., Thau, D., Stehman, S.V., Goetz, S.J., Loveland, T.R., Kommareddy, A., Egorov, A., Chini, L., Justice, C.O., Townshend, J.R.G., 2013. High-resolution global maps of 21st-century forest cover change. Science 342, 850-853.

Hanson, P.J., Huston, M.A., Todd, D.E., 2003. Walker Branch Throughfall Displacement Experiment. In: Hanson, P.J., Wullschleger, S.D. (Eds.), North American Temperate Deciduous Forest Responses to Changing Precipitation Regimes. Springer, New York, pp. 8-31. Hanson, P.J., Weltzin, J.F., 2000. Drought disturbance from climate change: response of United States forests. Sci. Total Environ. 262, 205-220. 
Hargrove, W.W., Pickering, J., 1992. Pseudoreplication: a sine qua non for regional ecology. Landscape Ecol. 6, 251-258.

Hargrove, W.W., Spruce, J.P., Gasser, G.E., Hoffman, F.M., 2009. Toward a national early warning system for forest disturbances using remotely sensed canopy phenology. Photogramm. Eng. Rem. S. 75, 1150-1156.

Heddinghaus, T.R., Sabol, P., 1991. A review of the Palmer Drought Severity Index and where do we go from here? In: Proceedings of the Seventh Conference on Applied Climatology. American Meteorological Society, Boston, pp. 242-246.

Heim, R.R., 2002. A review of twentieth-century drought indices used in the United States. B. Am. Meteorol. Soc. 83, 1149-1165.

Hogg, E.H., Brandt, J.P., Michaelian, M., 2008. Impacts of a regional drought on the productivity, dieback, and biomass of western Canadian aspen forests. Can. J. For. Res. 38, $1373-1384$.

Hu, J.I.A., Moore, D.J.P., Burns, S.P., Monson, R.K., 2010. Longer growing seasons lead to less carbon sequestration by a subalpine forest. Global Change Biol. 16, 771-783.

Huang, C.-Y., Anderegg, W.R.L., 2012. Large drought-induced aboveground live biomass losses in southern Rocky Mountain aspen forests. Global Change Biol. 18, 1016-1027.

Huete, A., Didan, K., Miura, T., Rodriguez, E.P., Gao, X., Ferreira, L.G., 2002. Overview of the radiometric and biophysical performance of the MODIS vegetation indices. Remote Sens. Environ. 83, 195-213.

Hurlbert, S.H., 1984. Pseudoreplication and the design of ecological field experiments. Ecol. Monogr. 54, 187-211. 
Hwang, T., Band, L.E., Miniat, C.F., Song, C., Bolstad, P.V., Vose, J.M., Love, J.P., 2014.

Divergent phenological response to hydroclimate variability in forested mountain watersheds.

Global Change Biol. 20, 2580-2595.

Karl, T.R., 1986. The sensitivity of the Palmer Drought Severity Index and Palmer's Z-Index to their calibration coefficients including potential evapotranspiration. J. Clim. Appl. Meteorol. $25,77-86$.

Keyantash, J., Dracup, J.A., 2002. The quantification of drought: an evaluation of drought indices. B. Am. Meteorol. Soc. 83, 1167-1180.

Klos, R.J., Wang, G.G., Bauerle, W.L., Rieck, J.R., 2009. Drought impact on forest growth and mortality in the southeast USA: an analysis using Forest Health and Monitoring data. Ecol. Appl. 19, 699-708.

Koch, F.H., Coulston, J.W., 2015. One-year (2013), three-year (2011-2013), and five-year (2009-2013) drought maps for the conterminous United States. In: Potter, K.M., Conkling, B.L. (Eds.), Forest Health Monitoring: National Status, Trends, and Analysis 2014. Gen. Tech. Rep. SRS-GTR-209. US Department of Agriculture, Forest Service, Southern Research Station, Asheville, North Carolina, pp. 57-71.

Koch, F.H., Smith, W.D., Coulston, J.W., 2013a. An improved method for standardized mapping of drought conditions. In: Potter, K.M., Conkling, B.L. (Eds.), Forest Health Monitoring: National Status, Trends, and Analysis 2010. Gen. Tech. Rep. SRS-GTR-176. US Department of Agriculture, Forest Service, Southern Research Station, Asheville, North Carolina, pp. 6783.

Koch, F.H., Smith, W.D., Coulston, J.W., 2013b. Recent drought conditions in the conterminous United States. In: Potter, K.M., Conkling, B.L. (Eds.), Forest Health Monitoring: National 
Status, Trends, and Analysis 2011. Gen. Tech. Rep. SRS-GTR-185. US Department of Agriculture, Forest Service, Southern Research Station, Asheville, North Carolina, pp. 41-58. Koch, F.H., Smith, W.D., Coulston, J.W., 2014. Drought patterns in the conterminous United States and Hawaii. In: Potter, K.M., Conkling, B.L. (Eds.), Forest Health Monitoring: National Status, Trends, and Analysis 2012. Gen. Tech. Rep. SRS-GTR-198. US Department of Agriculture, Forest Service, Southern Research Station, Asheville, North Carolina, pp. 49-72. Koch, F.H., Smith, W.D., Coulston, J.W., 2015. Drought patterns in the conterminous United States, 2012. In: Potter, K.M., Conkling, B.L. (Eds.), Forest Health Monitoring: National Status, Trends, and Analysis 2013. Gen. Tech. Rep. SRS-GTR-207. US Department of Agriculture, Forest Service, Southern Research Station, Asheville, North Carolina, pp. 55-69.

Kogan, F.N., 1995. Droughts of the late 1980s in the United States as derived from NOAA polarorbiting satellite data. B. Am. Meteorol. Soc. 76, 655-668.

Lamb, P.J., Changnon, S.A., 1981. On the "best" temperature and precipitation normals: the Illinois situation. J. Appl. Meteorol. 20, 1383-1390.

Laurance, W.F., 2004. Forest-climate interactions in fragmented tropical landscapes. Philos. T. R. Soc. B 359, 345-352.

Lawrimore, J., Heim, R.R., Svoboda, M., Swail, V., Englehart, P.J., 2002. Beginning a new era of drought monitoring across North America. B. Am. Meteorol. Soc. 83, 1191-1192. Lawrimore, J.H., Menne, M.J., Gleason, B.E., Williams, C.N., Wuertz, D.B., Vose, R.S., Rennie, J., 2011. An overview of the Global Historical Climatology Network monthly mean temperature data set, version 3. J. Geophys. Res. 116, D19121.

Liknes, G.C., Woodall, C.W., Perry, C.H., 2012. Using inventory data to determine the impact of drought on tree mortality. In: McWilliams, W., Roesch, F.A. (Eds.), Monitoring Across 
Borders: 2010 Joint Meeting of the Forest Inventory and Analysis (FIA) Symposium and the Southern Mensurationists, Knoxville, TN, 5-7 October 2010. US Department of Agriculture, Forest Service, Southern Research Station, Asheville, North Carolina, pp. 109-112.

Littell, J.S., McKenzie, D., Peterson, D.L., Westerling, A.L., 2009. Climate and wildfire area burned in western U.S. ecoprovinces, 1916-2003. Ecol. Appl. 19, 1003-1021.

Livezey, R.E., Vinnikov, K.Y., Timofeyeva, M.M., Tinker, R., van den Dool, H.M., 2007.

Estimation and extrapolation of climate normals and climatic trends. J. Appl. Meteorol. Clim. 46, 1759-1776.

Lobo, A., Maisongrande, P., 2006. Stratified analysis of satellite imagery of SW Europe during summer 2003: the differential response of vegetation classes to increased water deficit. Hydrol. Earth Syst. Sc. 10, 151-164.

Martínez-Vilalta, J., Lloret, F., Breshears, D.D., 2012. Drought-induced forest decline: causes, scope and implications. Biol. Letters 8, 689-691.

Mattson, W.J., Haack, R.A., 1987. The role of drought in outbreaks of plant-eating insects. Bioscience 37, 110-118.

McDowell, N., Pockman, W.T., Allen, C.D., Breshears, D.D., Cobb, N., Kolb, T., Plaut, J., Sperry, J., West, A., Williams, D.G., Yepez, E.A., 2008. Mechanisms of plant survival and mortality during drought: why do some plants survive while others succumb to drought? New Phytol. 178, 719-739.

McDowell, N.G., Coops, N.C., Beck, P.S.A., Chambers, J.Q., Gangodagamage, C., Hicke, J.A., Huang, C.-y., Kennedy, R., Krofcheck, D.J., Litvak, M., Meddens, A.J.H., Muss, J., NegrónJuarez, R., Peng, C., Schwantes, A.M., Swenson, J.J., Vernon, L.J., Williams, A.P., Xu, C., 
Zhao, M., Running, S.W., Allen, C.D., 2015. Global satellite monitoring of climate-induced vegetation disturbances. Trends Plant Sci. 20, 114-123.

McKee, T.B., Doesken, N.J., Kleist, J., 1993. The relationship of drought frequency and duration to time scales. In: Proceedings of the Eighth Conference on Applied Climatology. American Meteorological Society, Anaheim, California, pp. 179-184.

McRoberts, R.E., Tomppo, E.O., 2007. Remote sensing support for national forest inventories. Remote Sens. Environ. 110, 412-419.

Meddens, A.J.H., Hicke, J.A., Ferguson, C.A., 2012. Spatiotemporal patterns of observed bark beetle-caused tree mortality in British Columbia and the western United States. Ecol. Appl. 22, 1876-1891.

Mendelsohn, R., Kurukulasuriya, P., Basist, A., Kogan, F., Williams, C., 2007. Climate analysis with satellite versus weather station data. Climatic Change 81, 71-83.

Mendivelso, H.A., Camarero, J.J., Gutiérrez, E., Zuidema, P.A., 2014. Time-dependent effects of climate and drought on tree growth in a Neotropical dry forest: short-term tolerance vs. longterm sensitivity. Agr. Forest Meteorol. 188, 13-23.

Menne, M.J., Durre, I., Vose, R.S., Gleason, B.E., Houston, T.G., 2012. An overview of the Global Historical Climatology Network-Daily database. J. Atmos. Ocean. Tech. 29, 897-910. Meyn, A., White, P.S., Buhk, C., Jentsch, A., 2007. Environmental drivers of large, infrequent wildfires: the emerging conceptual model. Prog. Phys. Geog. 31, 287-312.

Mildrexler, D., Yang, Z., Cohen, W.B., Bell, D.M., 2016. A forest vulnerability index based on drought and high temperatures. Remote Sens. Environ. 173, 314-325.

Mildrexler, D.J., Zhao, M., Heinsch, F.A., Running, S.W., 2007. A new satellite-based methodology for continental-scale disturbance detection. Ecol. Appl. 17, 235-250. 
Mildrexler, D.J., Zhao, M., Running, S.W., 2009. Testing a MODIS global disturbance index across North America. Remote Sens. Environ. 113, 2103-2117.

Millar, C.I., Stephenson, N.L., 2015. Temperate forest health in an era of emerging megadisturbance. Science 349, 823-826.

Mishra, A.K., Singh, V.P., 2010. A review of drought concepts. J. Hydrol. 391, 202-216.

Mitchell, P.J., O'Grady, A.P., Hayes, K.R., Pinkard, E.A., 2014. Exposure of trees to droughtinduced die-off is defined by a common climatic threshold across different vegetation types. Ecol. Evol. 4, 1088-1101.

Monteith, J.L., 1965. Evaporation and environment. Sym. Soc. Exp. Biol. 19, 205-234.

Moore, G.W., Edgar, C.B., Vogel, J.G., Washington-Allen, R.A., March, R.G., Zehnder, R., 2016. Tree mortality from an exceptional drought spanning mesic to semiarid ecoregions. Ecol. Appl. 26, 602-611.

Morton, D.C., Nagol, J., Carabajal, C.C., Rosette, J., Palace, M., Cook, B.D., Vermote, E.F., Harding, D.J., North, P.R.J., 2014. Amazon forests maintain consistent canopy structure and greenness during the dry season. Nature 506, 221-224.

Mueller, R.C., Scudder, C.M., Porter, M.E., Trotter, R.T., Gehring, C.A., Whitham, T.G., 2005. Differential tree mortality in response to severe drought: evidence for long-term vegetation shifts. J. Ecol. 93, 1085-1093.

Myneni, R.B., Yang, W., Nemani, R.R., Huete, A.R., Dickinson, R.E., Knyazikhin, Y., Didan, K., Fu, R., Negrón Juárez, R.I., Saatchi, S.S., Hashimoto, H., Ichii, K., Shabanov, N.V., Tan, B., Ratana, P., Privette, J.L., Morisette, J.T., Vermote, E.F., Roy, D.P., Wolfe, R.E., Friedl, M.A., Running, S.W., Votava, P., El-Saleous, N., Devadiga, S., Su, Y., Salomonson, V.V., 
2007. Large seasonal swings in leaf area of Amazon rainforests. P. Natl. Acad. Sci. USA 104, 4820-4823.

Nielsen-Gammon, J.W., 2012. The 2011 Texas drought. Tex. Water J. 3, 59-95.

Niinemets, Ü., 2010. Responses of forest trees to single and multiple environmental stresses from seedlings to mature plants: past stress history, stress interactions, tolerance and acclimation. For. Ecol. Manage. 260, 1623-1639.

Palmer, W.C., 1965. Metereological drought. Research Paper No. 45. US Department of Commerce, Weather Bureau, Washington, District of Columbia.

Palmer, W.C., 1968. Keeping track of crop moisture conditions, nationwide: the new Crop Moisture Index. Weatherwise 21, 156-161.

Panu, U.S., Sharma, T.C., 2002. Challenges in drought research: some perspectives and future directions. Hydrolog. Sci. J. 47, S19-S30.

Park, S., Im, J., Jang, E., Rhee, J., 2016. Drought assessment and monitoring through blending of multi-sensor indices using machine learning approaches for different climate regions. Agr. Forest Meteorol. 216, 157-169.

Pasho, E., Camarero, J.J., de Luis, M., Vicente-Serrano, S.M., 2011. Impacts of drought at different time scales on forest growth across a wide climatic gradient in north-eastern Spain. Agr. Forest Meteorol. 151, 1800-1811.

Peters, A.J., Rundquist, D.C., Wilhite, D.A., 1991. Satellite detection of the geographic core of the 1988 Nebraska drought. Agr. Forest Meteorol. 57, 35-47.

Peters, A.J., Walter-Shea, E.A., Ji, L., Viña, A., Hayes, M., Svoboda, M.D., 2002. Drought monitoring with NDVI-based Standardized Vegetation Index. Photogramm. Eng. Rem. S. 68, 71-75. 
Peters, M.P., Iverson, L.R., Matthews, S.N., 2015. Long-term droughtiness and drought tolerance of eastern US forests over five decades. For. Ecol. Manage. 345, 56-64.

Peterson, G., Allen, C.R., Holling, C.S., 1998. Ecological resilience, biodiversity, and scale. Ecosystems 1, 6-18.

Pickett, S.T.A., 1989. Space-for-time substitution as an alternative to long-term studies. In: Likens, G.E. (Ed.), Long-Term Studies in Ecology: Approaches and Alternatives. SpringerVerlag, New York, pp. 110-135.

Raffa, K.F., Aukema, B.H., Bentz, B.J., Carroll, A.L., Hicke, J.A., Turner, M.G., Romme, W.H., 2008. Cross-scale drivers of natural disturbances prone to anthropogenic amplification: the dynamics of bark beetle eruptions. Bioscience 58, 501-517.

Riitters, K.H., Wickham, J.D., 2003. How far to the nearest road? Front. Ecol. Environ. 1, 125129.

Riitters, K.H., Wickham, J.D., O'Neill, R.V., Jones, K.B., Smith, E.R., Coulston, J.W., Wade, T.G., Smith, J.H., 2002. Fragmentation of continental United States forests. Ecosystems 5, 0815-0822.

Rouse, J.W., Haas, R.H., Schell, J.A., Deering, D.W., 1973. Monitoring vegetation systems in the Great Plains with ERTS. In: Freden, S.C., Mercanti, E.P., Becker, M.A. (Eds.), Third Earth Resources Technology Satellite-1 Symposium. NASA SP-351, Vol. I. National Aeronautics and Space Administration, Greenbelt, Maryland, pp. 309-317.

Saleska, S.R., Didan, K., Huete, A.R., da Rocha, H.R., 2007. Amazon forests green-up during 2005 drought. Science 318, 612.

Samanta, A., Ganguly, S., Myneni, R.B., 2011. MODIS Enhanced Vegetation Index data do not show greening of Amazon forests during the 2005 drought. New Phytol. 189, 11-15. 
Schowalter, T.D., Hargrove, W.W., Crossley, D.A., 1986. Herbivory in forested ecosystems. Annu. Rev. Entomol. 31, 177-196.

Schwartz, M.D., Hanes, J.M., 2010. Intercomparing multiple measures of the onset of spring in eastern North America. Int. J. Climatol. 30, 1614-1626.

Shaw, J.D., Steed, B.E., DeBlander, L.T., 2005. Forest Inventory and Analysis (FIA) annual inventory answers the question: What is happening to pinyon-juniper woodlands? J. Forest. $103,280-285$.

Sims, D.A., Brzostek, E.R., Rahman, A.F., Dragoni, D., Phillips, R.P., 2014. An improved approach for remotely sensing water stress impacts on forest C uptake. Global Change Biol. 20, 2856-2866.

Song, C., Woodcock, C.E., 2003. Monitoring forest succession with multitemporal Landsat images: factors of uncertainty. IEEE T. Geosci. Remote 41, 2557-2567.

Sousa, W.P., 1984. The role of disturbance in natural communities. Annu. Rev. Ecol. Syst. 15, 353-391.

Steinemann, A., 2003. Drought indicators and triggers: a stochastic approach to evaluation. J. Am. Water Resour. As. 39, 1217-1233.

Svoboda, M., LeComte, D., Hayes, M., Heim, R., Gleason, K., Angel, J., Rippey, B., Tinker, R., Palecki, M., Stooksbury, D., Miskus, D., Stephens, S., 2002. The Drought Monitor. B. Am. Meteorol. Soc. 83, 1181-1190.

Svoboda, M.D., Hayes, M.J., Wilhite, D.A., Tadesse, T., 2004. Recent advances in drought monitoring. Paper J2.4. In: 14th Conference on Applied Climatology, 10-16 January 2004. American Meteorological Society, Seattle, Washington. 
Tadesse, T., Brown, J.F., Hayes, M.J., 2005. A new approach for predicting drought-related vegetation stress: Integrating satellite, climate, and biophysical data over the U.S. central plains. ISPRS J. Photogramm. 59, 244-253.

Thornthwaite, C.W., 1948. An approach towards a rational classification of climate. Geogr. Rev. $38,55-94$.

Tilman, D., 1989. Ecological experiments: strengths and conceptual problems. In: Likens, G.E. (Ed.), Long-Term Studies in Ecology: Approaches and Alternatives. Springer-Verlag, New York, pp. 136-157.

Trenberth, K.E., Dai, A., van der Schrier, G., Jones, P.D., Barichivich, J., Briffa, K.R., Sheffield, J., 2014. Global warming and changes in drought. Nature Clim. Change 4, 17-22.

Trouet, V., Taylor, A.H., Wahl, E.R., Skinner, C.N., Stephens, S.L., 2010. Fire-climate interactions in the American West since 1400 CE. Geophys. Res. Lett. 37, L04702.

Trumbore, S., Brando, P., Hartmann, H., 2015. Forest health and global change. Science 349, 814-818.

Tucker, C.J., 1979. Red and photographic infrared linear combinations for monitoring vegetation. Remote Sens. Environ. 8, 127-150.

USDA Forest Service, 2015. Timber sold and harvested, 1905-2012, National Forest System. http://www.fs.fed.us/forestmanagement/documents/sold-harvest/documents/19052012_Natl_Summary_Graph.pdf (accessed April 13 2016).

Vicente-Serrano, S.M., Beguería, S., López-Moreno, J.I., 2010. A multiscalar drought index sensitive to global warming: the Standardized Precipitation Evapotranspiration Index. J. Climate 23, 1696-1718. 
Vicente-Serrano, S.M., Beguería, S., Lorenzo-Lacruz, J., Camarero, J.J., López-Moreno, J.I., Azorin-Molina, C., Revuelto, J., Morán-Tejeda, E., Sanchez-Lorenzo, A., 2012. Performance of drought indices for ecological, agricultural, and hydrological applications. Earth Interact. 16, 1-27.

Vicente-Serrano, S.M., Gouveia, C., Camarero, J.J., Beguería, S., Trigo, R., López-Moreno, J.I., Azorín-Molina, C., Pasho, E., Lorenzo-Lacruz, J., Revuelto, J., Morán-Tejeda, E., SanchezLorenzo, A., 2013. Response of vegetation to drought time-scales across global land biomes. P. Natl. Acad. Sci. USA 110, 52-57.

Vitasse, Y., Porté, A., Kremer, A., Michalet, R., Delzon, S., 2009. Responses of canopy duration to temperature changes in four temperate tree species: relative contributions of spring and autumn leaf phenology. Oecologia 161, 187-198.

Volaire, F., Norton, M., 2006. Summer dormancy in perennial temperate grasses. Ann. Bot.London 98, 927-933.

Wang, W., Peng, C., Kneeshaw, D.D., Larocque, G.R., Luo, Z., 2012. Drought-induced tree mortality: ecological consequences, causes, and modeling. Environ. Rev. 20, 109-121.

Westerling, A.L., Hidalgo, H.G., Cayan, D.R., Swetnam, T.W., 2006. Warming and earlier spring increase western U.S. forest wildfire activity. Science 313, 940-943.

White, M.A., Hoffman, F., Hargrove, W.W., Nemani, R.R., 2005. A global framework for monitoring phenological responses to climate change. Geophys. Res. Lett. 32, L04705.

Wilhite, D., Svoboda, M., Hayes, M., 2007. Understanding the complex impacts of drought: A key to enhancing drought mitigation and preparedness. Water Resour. Manage. 21, 763-774. Wilks, D.S., 2013. Projecting "normals" in a nonstationary climate. J. Appl. Meteorol. Clim. 52, 289-302. 
Williams, A.P., Allen, C.D., Macalady, A.K., Griffin, D., Woodhouse, C.A., Meko, D.M., Swetnam, T.W., Rauscher, S.A., Seager, R., Grissino-Mayer, H.D., Dean, J.S., Cook, E.R., Gangodagamage, C., Cai, M., McDowell, N.G., 2013. Temperature as a potent driver of regional forest drought stress and tree mortality. Nature Clim. Change 3, 292-297.

Williams, A.P., Allen, C.D., Millar, C.I., Swetnam, T.W., Michaelsen, J., Still, C.J., Leavitt, S.W., 2010. Forest responses to increasing aridity and warmth in the southwestern United States. P. Natl. Acad. Sci. USA 107, 21289-21294.

Wu, J., Albert, L.P., Lopes, A.P., Restrepo-Coupe, N., Hayek, M., Wiedemann, K.T., Guan, K., Stark, S.C., Christoffersen, B., Prohaska, N., Tavares, J.V., Marostica, S., Kobayashi, H., Ferreira, M.L., Campos, K.S., da Silva, R., Brando, P.M., Dye, D.G., Huxman, T.E., Huete, A.R., Nelson, B.W., Saleska, S.R., 2016. Leaf development and demography explain photosynthetic seasonality in Amazon evergreen forests. Science 351, 972-976.

Zhang, Y., Peng, C., Li, W., Fang, X., Zhang, T., Zhu, Q., Chen, H., Zhao, P., 2013. Monitoring and estimating drought-induced impacts on forest structure, growth, function, and ecosystem services using remote-sensing data: recent progress and future challenges. Environ. Rev. 21, $103-115$. 
Figure captions

Figure 1: Percent change in maximum three-week NDVI for the period ending August 28, 2011 compared to the mean of the period maximums for the 2000-2010 era for all land cover types in the Southern Great Plains, USA as tracked in the ForWarn system (Hargrove et al., 2009). Departures are extreme across eastern New Mexico, west and central Texas and western Oklahoma where grass and shrublands predominate. Drought impacts on NDVI extend well into the forests of east Texas and Oklahoma, then diminish across surrounding states.

Figure 2: A conceptual model of how a "big data" integration approach might be employed in a system for monitoring drought impacts in forests. Remotely sensed data, such as NDVI departure, and meteorological data, via calculated drought indices, provide a coarse indicator of drought. A more accurate sense of potential drought impacts can be derived by filtering expectations through ancillary wildland fire, insect and disease, land cover and phenology datasets; confirmation of actual drought impacts requires detailed analyses or field data, such as from Forest Inventory and Analysis (FIA) surveys.

Figure 3: A comparison of two nearby woodland pixels in west Texas, USA on similar sites, one that burned and one that did not during 2011 as tracked by the ForWarn system (Hargrove et al., 2009). Note that the changes that initiated in early 2011 persisted through 2012 on both sites, but that the cumulative effects of drought and wildfire were more pronounced than drought 
alone. Site locations: unburned site location 31.8295, -100.6636; burned site location: 31.8390, 100.6455 .

Figure 4: Mean NDVI for a random sample of unburned majority forest, shrub or grass pixels within the National Climatic Data Center's Texas Climate Divisions 1,2,5,and 6 (west Texas; ftp://ftp.ncdc.noaa.gov/pub/data/cirs/) using the ForWarn dataset (Hargrove et al., 2009). Note the extreme decline in NDVI during the 2011 drought that affected all vegetation types.

Figure 5: Correlations between mean March-September MODIS-based ForWarn NDVI and mean monthly March-September Palmer Modified Drought Index (PMDI) of NCDC's Climate Divisions for different land cover types. The cover type for each $240 \mathrm{~m}$ MODIS pixel was determined based on the majority type of the National Land Cover Dataset (NLCD) pixels corresponding to each MODIS pixel. Map A shows 13-year correlations (2000-2012) for all forest pixels, with areas of known disturbance from wildland fire, insects or diseases in black. The other maps show correlations for majority conifer (B), hardwood (C), shrub (D), grassland (E), and crop (F) cover types. Wildland fire was derived from MTBS.gov (2000-2012); insect and disease disturbance was compiled from USDA Forest Service Forest Health Protection Insect and Disease Survey (IDS) data. Pearson's R correlations were based on 250,000 random points, sampled with a 1-km buffer. 


\begin{tabular}{|c|c|c|c|c|}
\hline Dataset & $\begin{array}{l}\text { Developers/ } \\
\text { Owners }\end{array}$ & Contents & Value Added for Drought Detection & Reference \\
\hline $\begin{array}{l}\text { National Land Cover } \\
\text { Database (NLCD); NLCD } \\
2011 \text { USFS Tree Canopy } \\
\text { product }\end{array}$ & $\begin{array}{l}\text { USGS, along with the } \\
\text { Multi-Resolution } \\
\text { Land Characteristics } \\
\text { (MRLC) Consortium }\end{array}$ & $\begin{array}{l}\text { 16-class Landsat-based } 30 \mathrm{~m} \\
\text { resolution land cover database for } \\
\text { the United States; updated every } \\
\text { five years; Tree Canopy product } \\
\text { provides estimated percent } \\
\text { canopy cover plus standard error }\end{array}$ & $\begin{array}{l}\text { Shows vegetation and land cover types } \\
\text { to assist estimation of drought impacts } \\
\text { across areas with variable sensitivity; } \\
\text { enables land cover conditional filtering } \\
\text { of drought impacts }\end{array}$ & http://www.mrlc.gov/ \\
\hline $\begin{array}{l}\text { Snowpack/ } \\
\text { SNOTEL }\end{array}$ & NOAA & $\begin{array}{l}\text { Ground-based remote sensing of } \\
\text { snow accumulations }\end{array}$ & $\begin{array}{l}\text { Future drought impacts in areas } \\
\text { dependent on snowmelt water }\end{array}$ & http://www.nohrsc.noaa.gov/nsa \\
\hline $\begin{array}{l}\text { MODIS hotspots showing } \\
\text { recent wildfires }\end{array}$ & $\begin{array}{l}\text { NASA, Remote } \\
\text { Sensing Applications } \\
\text { Center (RSAC) } \\
\text { Active Fire Mapping } \\
\text { Program }\end{array}$ & $\begin{array}{l}\text { Thermal detection of wildfires at } \\
1 \mathrm{~km} \text { resolution }\end{array}$ & $\begin{array}{l}\text { Fire may be the final outcome of } \\
\text { drought; separates fire effects from } \\
\text { extreme drought effects }\end{array}$ & http://activefiremap.fs.fed.us \\
\hline $\begin{array}{l}\text { Monitoring Trends in Burn } \\
\text { Severity (MTBS) and } \\
\text { GeoMAC }\end{array}$ & $\begin{array}{l}\text { Remote Sensing } \\
\text { Applications Center } \\
\text { (RSAC) and USGS }\end{array}$ & $\begin{array}{l}\text { Mapped perimeters of past } \\
\text { wildfires, with burn severity } \\
\text { estimates }\end{array}$ & $\begin{array}{l}\text { Fire may be the final outcome of } \\
\text { drought; separates fire effects from } \\
\text { extreme drought effects }\end{array}$ & $\begin{array}{l}\text { http://www.mtbs.gov, } \\
\text { http://www.geomac.gov }\end{array}$ \\
\hline Active Fire Maps & $\begin{array}{l}\text { Incident Information } \\
\text { System (INCIWEB) }\end{array}$ & $\begin{array}{l}\text { Status of active wildfires and } \\
\text { large prescribed burns }\end{array}$ & $\begin{array}{l}\text { Fire progression maps show effects of } \\
\text { near real-time drought conditions }\end{array}$ & http://www.inciweb.org \\
\hline $\begin{array}{l}\text { Historical Insect and } \\
\text { Disease Survey (IDS) Maps }\end{array}$ & $\begin{array}{l}\text { Forest Health } \\
\text { Technology } \\
\text { Enterprise Team } \\
\text { (FHTET) }\end{array}$ & $\begin{array}{l}\text { Aerial disturbance surveys from } \\
\text { aircraft for a portion of US forests }\end{array}$ & $\begin{array}{l}\text { Shows the pattern and landscape } \\
\text { position of pest mortality and } \\
\text { defoliation events }\end{array}$ & $\begin{array}{l}\text { http://www.fs.fed.us/foresthealth/ } \\
\text { technology }\end{array}$ \\
\hline Stream depth and flow & $\begin{array}{l}\text { USGS Stream Gauge } \\
\text { Network }\end{array}$ & $\begin{array}{l}\text { Depth and Amount of Flow of } \\
\text { Rivers and Streams }\end{array}$ & $\begin{array}{l}\text { Monitor changes in runoff and surface } \\
\text { flow downstream of drought areas }\end{array}$ & http://waterdata.usgs.gov \\
\hline $\begin{array}{l}\text { LANDFIRE Disturbance } \\
\text { Database }\end{array}$ & $\begin{array}{l}\text { USDA Forest Service } \\
\text { LANDFIRE }\end{array}$ & $\begin{array}{l}\text { Vegetation and Fuel Disturbances } \\
1999-2010\end{array}$ & $\begin{array}{l}\text { Separate other disturbances and } \\
\text { harvests from drought mortality }\end{array}$ & $\begin{array}{l}\text { http://www.landfire.gov/disturag } \\
\text { ce.php }\end{array}$ \\
\hline
\end{tabular}




\begin{tabular}{|l|l|l|l|}
\hline $\begin{array}{l}\text { Forest Inventory and } \\
\text { Analysis (FIA) }\end{array}$ & USDA Forest Service & $\begin{array}{l}\text { Inventoried forest plots in a } \\
\text { statistical design, re-measured } \\
\text { every } 5 / 10 \text { years }\end{array}$ & $\begin{array}{l}\text { Shows long-term cumulative effects } \\
\text { and mortality of drought }\end{array}$ \\
\hline $\begin{array}{l}\text { Phenology data, } \\
\text { phenoregion maps }\end{array}$ & $\begin{array}{l}\text { USGS, USDA Forest } \\
\text { Service }\end{array}$ & $\begin{array}{l}\text { NDVI and other Vegetation } \\
\text { Indices, Statistically created maps } \\
\text { of multivariate clusters of NDVI } \\
\text { through time }\end{array}$ & $\begin{array}{l}\text { Shows departure from normal timing } \\
\text { of greenness, maps major vegetation } \\
\text { types having similar phenology } \\
\text { behavior, empirically determined }\end{array}$ \\
\hline
\end{tabular}

Table 1. Ancillary geographic datasets that may refine assessments of drought impacts for the United States. These datasets can refine interpretations from coarse drought response measures, such as change in the Normalized Drought Severity Index (NDVI), as part of an integrated "big data" approach to drought detection and monitoring. 



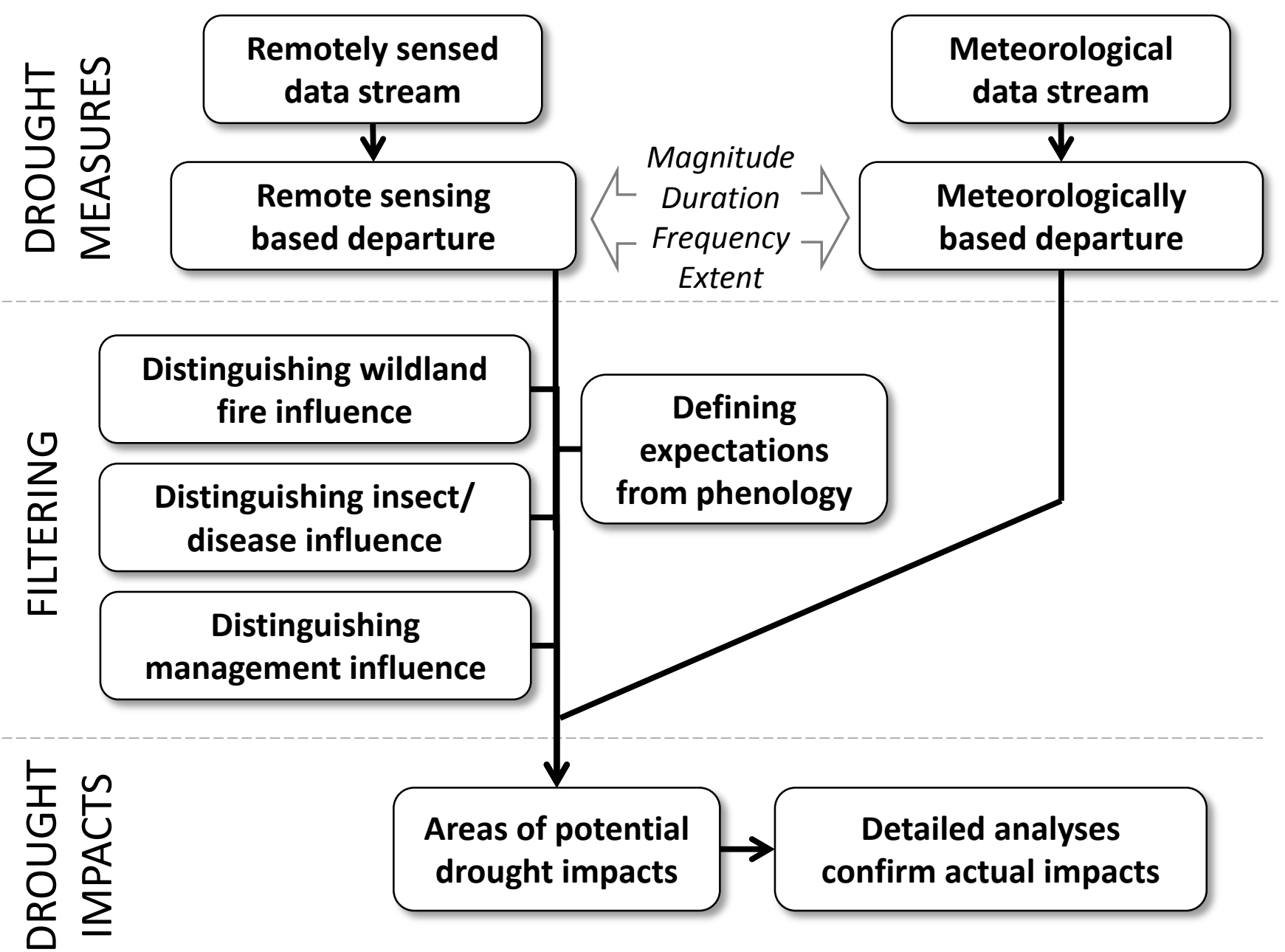




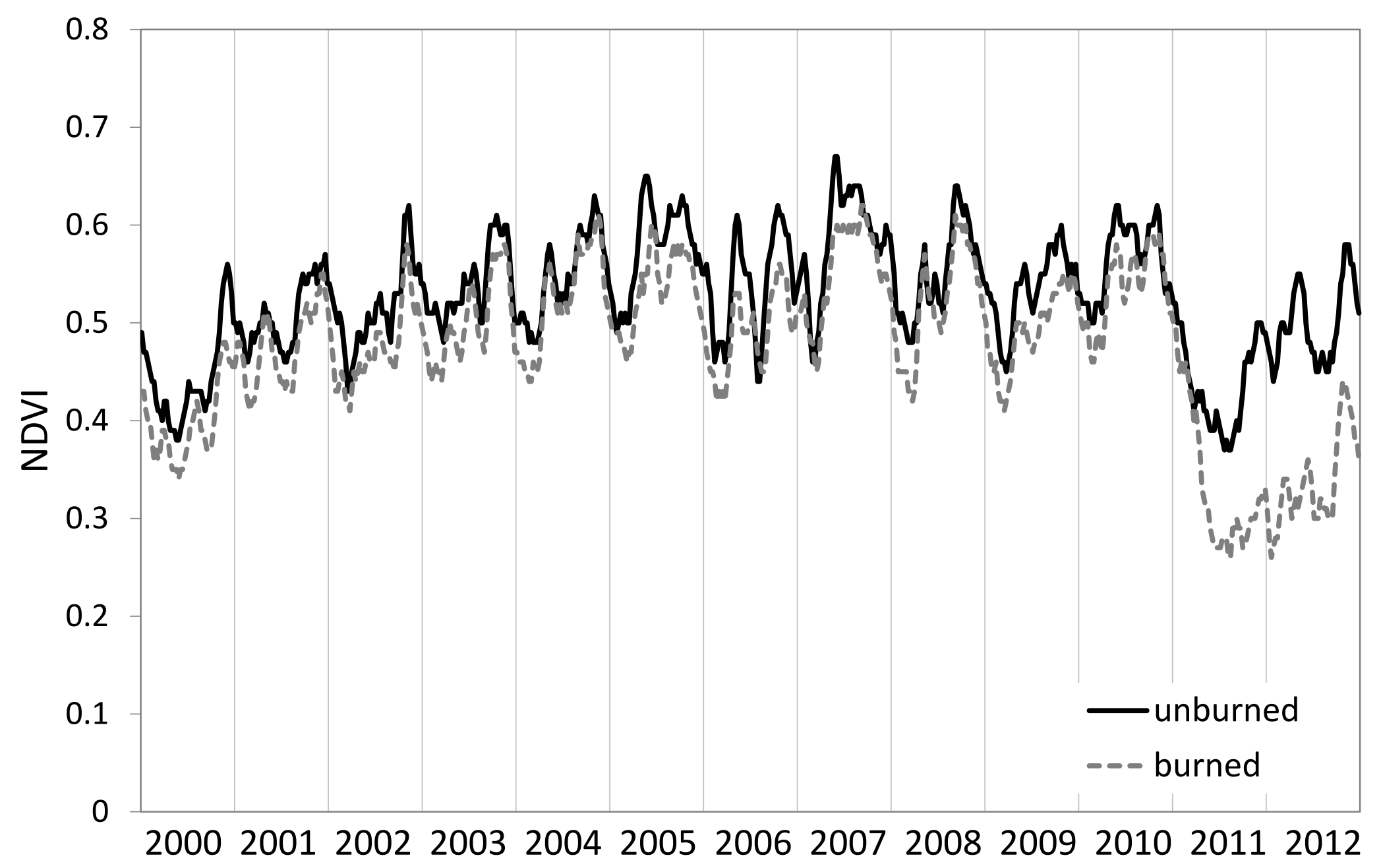




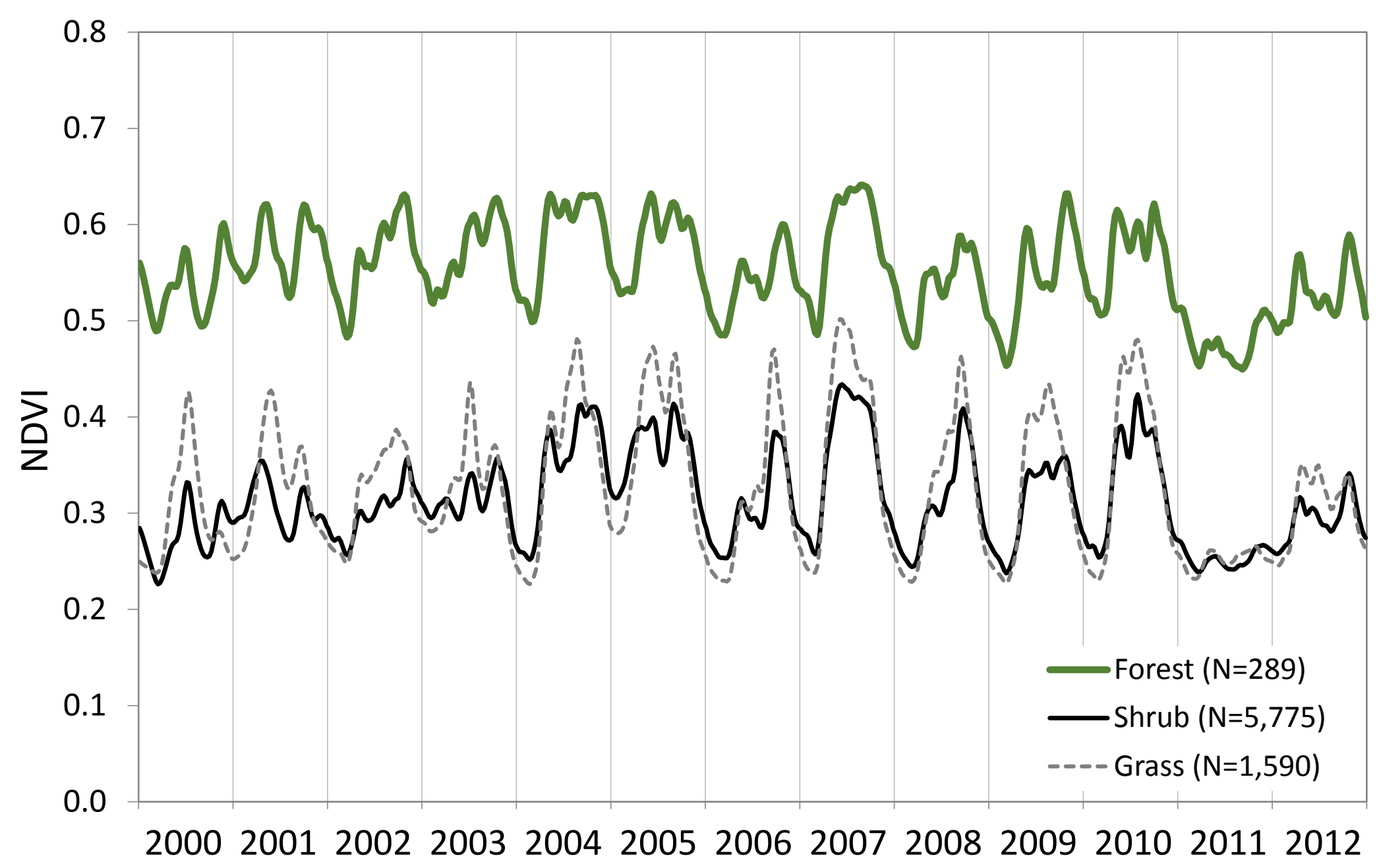


A.

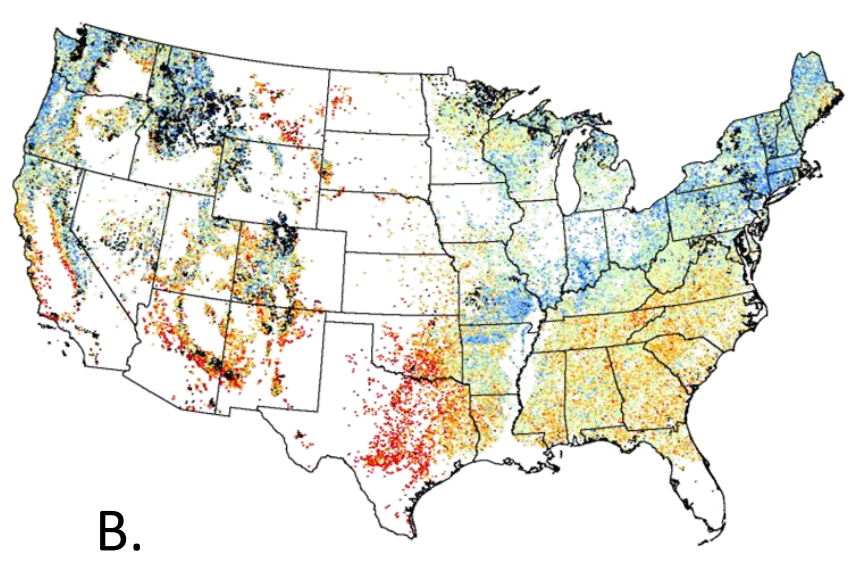

B.
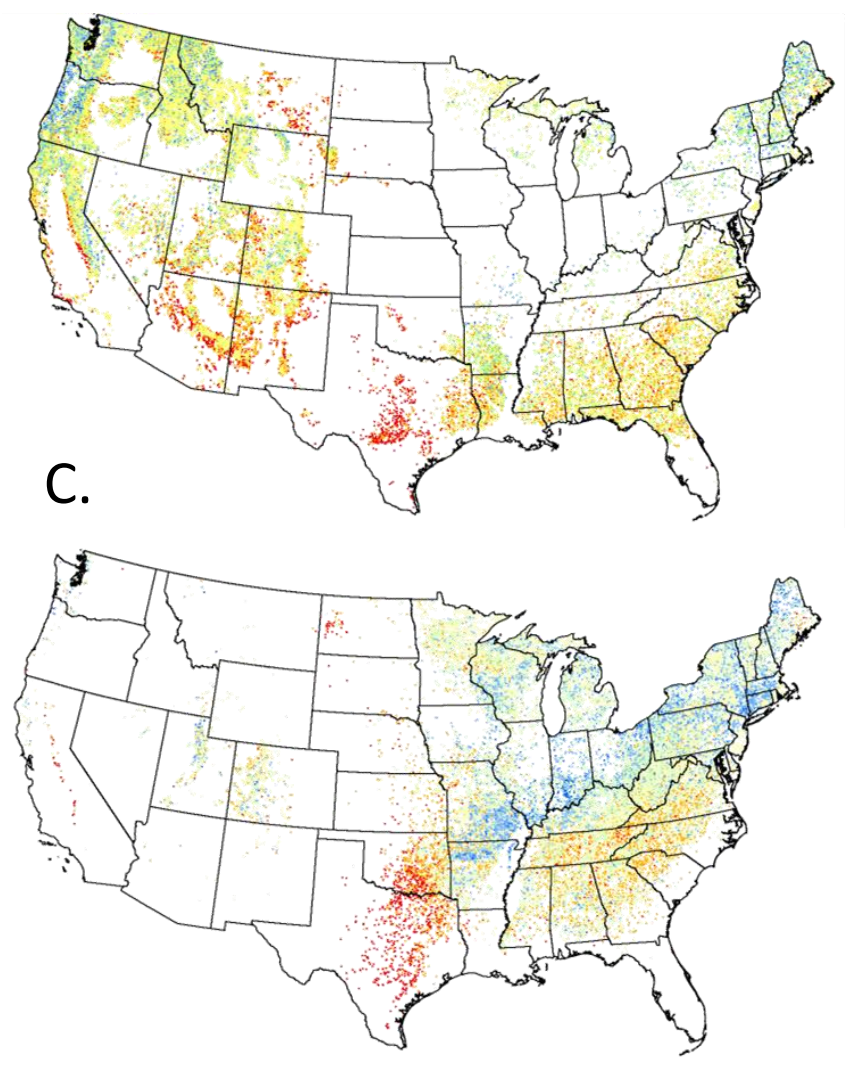

D.
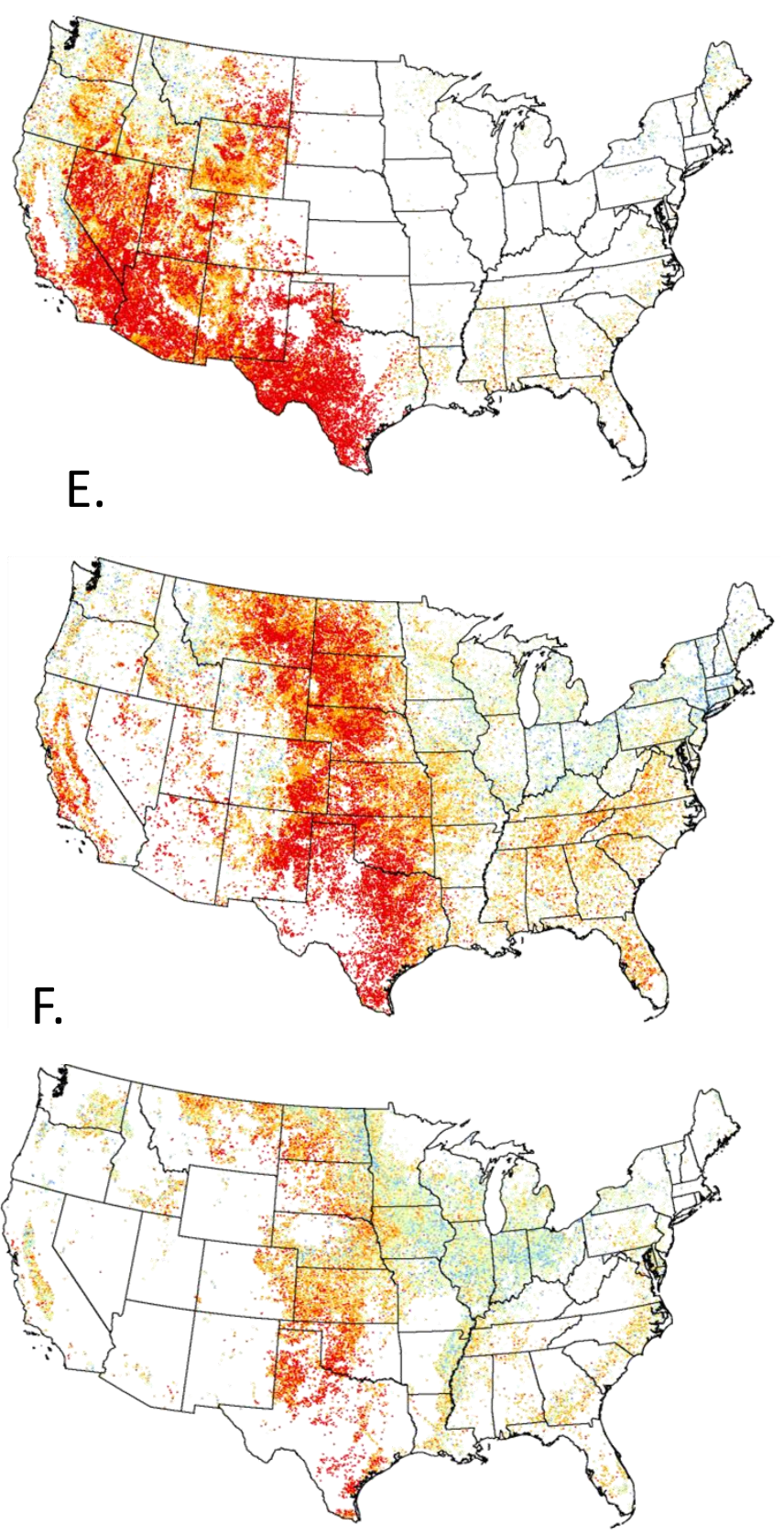

- -1.00 to -0.67

o -0.66 to -0.33

- -0.33 to 0.00

$\circ+0.01$ to +0.33

o +0.34 to +0.66

o +0.67 to +1.00

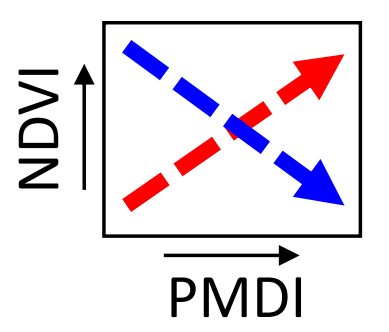

